Estudios Constitucionales, Año 10, No 2, 2012, pp. 535 - 574.

ISSN 0718-0195

Centro de Estudios Constitucionales de Chile Universidad de Talca

"El control de convencionalidad y el cumplimiento de las sentencias de la Corte Interamericana" Juan Carlos Hitters

\title{
EL CONTROL DE CONVENCIONALIDAD Y EL CUMPLIMIENTO DE LAS SENTENCIAS DE LA CORTE INTERAMERICANA (Supervisión Supranacional. Cláusula Federal)
}

Juan Carlos Hitters ${ }^{1}$

I. Efecto de las sentencias de la CORTE IDH en el derecho interno. A. Valor de las sentencias. B. Supervisión del cumplimiento. II. Cláusula federal. A. Cláusula federal (Federalismo y división de Poderes). B. Nación y Provincias (o Estados Federales). Deslinde de competencias. C. Cuestiones Federales. El deslinde de las competencias y la jurisprudencia de la Corte Suprema de la Nación. III. Modalidades de cumplimiento de las sentencias de la CORTE IDH en el derecho interno. A. Modalidad de recepción. B. Supervisión de cumplimiento. Casos Argentinos en supervisión. 1. Caso Bayarri Vs. Argentina. Supervisión de Cumplimiento de Sentencia. Resolución de la Corte Interamericana de Derechos Humanos 22 de noviembre de 2010. 2. Caso Kimel Vs. Argentina. Supervisión de Cumplimiento de Sentencia. Resolución de la Corte Interamericana de Derechos Humanos 15 de noviembre de 2010. 3. Caso Cantos Vs. Argentina. Supervisión de Cumplimiento de Sentencia. Resolución de la Corte Interamericana de Derechos Humanos de 26 de agosto de 2010. 4. Caso Bulacio Vs. Argentina. Supervisión de Cumplimiento de Sentencia. Resolución de la Corte Interamericana de Derechos Humanos de 26 de noviembre de 2008. 5. Caso Garrido y Baigorria Vs. Argentina. Supervisión de Cumplimiento de Sentencia. Resolución de la Corte Interamericana de Derechos Humanos de 27 de noviembre de 2007. 6. Corte IDH. Caso Bueno Alves Vs. Argentina. Supervisión de Cumplimiento de Sentencia. Resolución de la Corte Interamericana de Derechos Humanos 5 de julio de 2011. C. Casos Argentinos que todavía no se encuentran en supervisión de cumplimiento. 1. Jorge Fontevecchia y Héctor D’amico Vs. República Argentina (Caso No 12.524). 2. Milagros Fornerón y Leonardo Aníbal Fornerón Vs. República Argentina (Caso No 12.584). 3. Jorge Fernando Grande Vs. República Argentina (caso 11.498). 4. Iván Eladio Torres Millacura Vs. Argentina (caso No 12.533). D. Casos en la Provincia de Buenos Aires. 1. Caso Sergio Andrés Schiavini y Maria Teresa Schnack (Caso No 12.080). 2. Caso Fernando Horacio Giovanelli (Caso No 12.298). 3. Caso Gabriel Egisto Santillán (Caso No 12.159). 4. Caso Jorge Omar Gutiérrez y familia (Caso No 12.221). IV. Resumen final. A. Recepción de las sentencias de la Corte IDH en

\footnotetext{
${ }^{1}$ Abogado egresado de la Universidad Nacional de La Plata y Doctor en Ciencias Jurídicas y Sociales (UNLP), fue Convencional Nacional Constituyente en 1994 y subsecretario de Justicia provincial entre 1991 y 1994. Es Profesor titular en la Facultad de Ciencias Jurídicas y Sociales de la UNLA, a la que ingresó en 1966 y Profesor Emérito y Honorario de las Universidades de San Agustín de Perú y Central de Chile, respectivamente. Magistrado de la Suprema Corte de Justicia de la Provincia de Buenos Aires. Argentina.
} 
el ámbito interno. 1. Obligatoriedad de las sentencias. 2. Mecanismos de recepción. 3. Ejecución y cumplimiento. 4. Supervisión del cumplimiento de las sentencias efectuado por la Corte IDH. $B$. División de poderes y federalismo. C. Experiencias Argentinas. D. La situación en la Provincia de Buenos Aires.

\section{EFeCTO De LAS SENTENCIAS DE LA CoRTe IDH EN EL DERECHO INTERNO}

\section{A. Valor de las sentencias}

Resulta por de más sabido que las sentencias que emite la Corte Interamericana de Derechos Humanos "son obligatorias" y, según lo dispone el artículo 68 de la CADH, los Estados se comprometen a cumplirlas "en todo caso en que sean partes" (inciso 1). Aclara dicha norma en su inciso 2 que cuando el fallo disponga "indemnización compensatoria se podrá ejecutar en el respectivo país por el procedimiento interno vigente para la ejecución de sentencias contra el Estado”.

El Tribunal regional que surge del Pacto de San José de Costa Rica ha expresado en reiteradas oportunidades que sus pronunciamientos son vinculantes para los litigantes, por lo que deben ser acatados en forma irrestricta ${ }^{2}$.

Veremos a lo largo de este trabajo de qué manera los países que son condenados por ese cuerpo jurisdiccional recepcionan tales sentencias, y en qué medida les dan vía libre.

Es importante ver cómo las providencias emitidas por la Comisión IDH y por la Corte IDH se han derramado en el ámbito doméstico ${ }^{3}$; y en paralelo observar la importancia del contralor heterónomo que efectúan esos dos cuerpos, que han terminado no sólo por inspeccionar el cumplimiento de ciertas convenciones internacionales, sino también -y por vía excepcional-a las propias decisiones de los jueces locales ${ }^{4}$.

Todo ello ha logrado "verdaderas mutaciones" en los sistemas domésticos, tanto de origen sustancial como adjetivo. Las mismas han tenido su origen sin

2 García Ramírez, Sergio, Los Derechos Humanos y la jurisdicción interamericana, UNAM, México, 2001, p. 156.

${ }^{3}$ Hitters, Juan C., ¿Son vinculantes los pronunciamientos de la Comisión y de la Corte Interamericana de Derechos Humanos? Control de constitucionalidad y convencionalidad, Revista La Ley, Buenos Aires, 2008-E, p. 1169.

${ }^{4}$ Hitters, Juan C., Los Tribunales Supranacionales, Revista La Ley, Buenos Aires, 2006-E, p. 817. Véase también Monterisi, Ricardo, La Corte Interamericana de Derechos Humanos y el Impacto de sus Sentencias, Revista La Ley, Buenos Aires, 8 de marzo de 2012, p. 1. 
duda en los fallos del Tribunal regional que "progresivamente" han permeado directa o indirectamente en los distintos recovecos de los andariveles del derecho interno.

Para dar un solo ejemplo, digamos que a través del pronunciamiento en el caso La Última Tentación de Cristo (Olmedo Bustos)', Chile tuvo que corregir su propia Constitución, tema que más adelante retomaremos.

Desde esa misma vertiente, en 2005 en el caso Palamara Iribarne Vs. Chile 6 el Tribunal interamericano ordenó dejar sin efecto sentencias condenatorias dictadas en 1995 por la Corte Marcial de la Armada, que habían dispuesto la prohibición de la publicación de un libro que abordaba aspectos relacionados con la inteligencia militar. Aquel tribunal dispuso en paralelo que el Estado debía permitir la edición de dicha obra.

En 2006 en el caso Almonacid Arellano y otros Vs. Chile citando a Barrios Altos repitió el criterio de la imprescriptibilidad de las leyes de amnistía y dijo enfáticamente que en el derecho interno el Estado debe dejar sin efecto las resoluciones y sentencias dictadas sobre esta problemática -que permitían la impunidad-y remitir las actuaciones a la justicia ordinaria, para que dentro de un pronunciamiento penal se identifique y sancione a todos los responsables de la muerte del señor Almonacid Arellano ${ }^{7}$.

También en 2006, en el caso Claude Reyes y otros Vs. Chile ${ }^{8}$ la Corte IDH condenó a dicho país trasandino a modificar su legislación doméstica. En efecto, la Comisión Interamericana presentó una demanda con el fin de que se declarara que el Estado fue responsable por la violación de los derechos consagrados en los arts. 13 (Libertad de Pensamiento y Expresión) y 25 (Derecho a la Protección Judicial). Señaló allí, en su pretensión liminar, que las autoridades locales se habían negado a brindar a Marcel Claude Reyes y

\footnotetext{
${ }^{5}$ Corte IDH, Caso La Última Tentación de Cristo (Olmedo Bustos y otros) Vs. Chile, Sentencia de 5 de febrero de 2001, Serie C No 73; Caso Barrios Altos Vs. Perú, Sentencia de 14 de marzo de 2001, Serie C No 75, Caso La Cantuta Vs. Perú, Sentencia de 29 de noviembre de 2006. Serie C No 162, y Caso del Tribunal Constitucional Vs. Perú, Sentencia de 31 de enero de 2001, Serie C No 71.

${ }^{6}$ Corte IDH, Caso Palamara Iribarne Vs. Chile, Sentencia de 22 de noviembre de 2005, Serie C No 135 , párr. 9.

${ }^{7}$ Corte IDH, Caso Almonacid Arellano y otros Vs. Chile, Sentencia de 26 de septiembre de 2006, Serie C No 154, párr. 148. Véase el Dictamen del Perito propuesto por la Comisión Humberto Raúl Ignacio Nogueira Alcalá, quien hace un detallado análisis del derecho interno chileno, párr. 72, c.

${ }^{8}$ Corte IDH, Caso Claude Reyes y otros Vs. Chile, Sentencia de 19 de septiembre de 2006, Serie C No 151.
} 
otros la información requerida ante el Comité de Inversiones Extranjeras, con referencia a una empresa forestal relacionada con un proyecto de deforestación, por ser perjudicial -según los denunciantes- para el medioambiente e impedir el desarrollo sostenido de Chile. Finalmente, la Corte -tal cual lo adelantamos- hizo lugar a dicha pretensión e indicó que se debía adecuar el derecho interno para posibilitar la publicidad de los actos de gobierno?

Recuérdese también que en Guatemala la Corte IDH suspendió la pena de muerte en un asunto concreto a través de una medida provisional. En el mismo sentido el más alto cuerpo judicial Argentino -siguiendo dichas pautas- ha permitido la modificación de sentencias que habían pasado en autoridad de cosa juzgada en el sector local, o la aplicación retroactiva de la ley penal en perjuicio del acusado (Bulacio, Simón, entre otros). Este Tribunal doméstico en el caso Casal $^{10}$ pegó un verdadero brinco para responder a lo normado en el artículo 8, 2, h, del Pacto de San José (en cuanto a la doble instancia) al ampliar - por vía jurisdiccional- la competencia de la Cámara de Casación Penal atribuyéndole tareas casi propias de la alzada ${ }^{11}$.

Desde tal óptica, no olvidemos que esa Corte, poniendo en juego la jurisprudencia internacional, ha dado instrucciones a los jueces inferiores para que eviten el agravamiento de las condiciones carcelarias y, aún más, intimó a los poderes legislativos y ejecutivos bonaerenses para que adecuen la legislación procesal y las prácticas carcelarias a los estándares nacionales e internacionales ${ }^{12}$.

Otro ejemplo de lo que venimos marcando -sobre el que luego volveremos- lo tenemos en los Estados Unidos de México ${ }^{13}$ cuando la Corte

\footnotetext{
9 Acatando tal decisorio, Chile dictó una ley que disponía que, a partir de abril de 2009 -cuando entre en vigencia dicha normativa- el requerimiento de información hecho por cualquier ciudadano a un organismo público, sobre una resolución de su área, deberá ser respondido en un máximo de 20 días. De esa forma el fallo sentó jurisprudencia reconociendo por primera vez el derecho de acceso a la información pública como un derecho fundamental y parte de la columna basal del sistema democrático, extensible -según creo- a todo el ámbito interamericano en la medida en que se den similares circunstancias fácticas.

${ }^{10}$ Véase Morello, Augusto, González Campaña, Germán, Reformulación de la casación penal, Revista La Ley, Buenos Aires, Suplemento Penal, octubre, 2005, p. 16.

${ }^{11}$ CSJN, Casal, Matías Eugenio y otro s/ robo simple en grado de tentativa, causa No 1681. C. 1757. XL. Fallo del 20/09/05.

${ }^{12}$ CSJN, Verbitsky, Horacio s/ habeas corpus, sentencia del 3 de mayo de 2005, V. 856. XXXVIII.

${ }^{13}$ Recordemos que en el caso Castañeda Gutman Vs. México del 6 de agosto de 2008, ese país fue por primera vez condenado por la Corte IDH (véase Ferrer Mac-Gregor, Eduardo, "El caso Castañeda ante
} 
Interamericana, en el caso Radilla Pachecho $o^{14}$, condenó a ese país por la violación de varios derechos consignados en la $\mathrm{CADH}^{15}$, ordenando reformar el artículo 57 del Código de Justicia Militar referente a la imposibilidad de juzgar a los civiles en dicho fuero (párrs. 277 y 300) ${ }^{16}$. Y posteriormente, cuando llevó a cabo la Supervisión de Cumplimiento de la Sentencia ${ }^{17}$, insistió en la necesidad de concluir las modificaciones legislativas ordenadas ${ }^{18}$. Tal apertura ha implicado que esa Nación reformara recientemente su propia Carta Magna Nacional ${ }^{19}$, incluyendo en su artículo 1 la problemática de los Derechos Humanos ${ }^{20}$.

la Corte Interamericana de Derechos Humanos”, Editorial Porrúa México y UNAM, México, año 2009, pp. 3 y siguientes.

${ }^{14}$ Corte IDH, Caso Radilla Pacheco Vs. México, Sentencia de 23 de noviembre de 2009, Serie C No 209.

15 El señor Radilla Pachecho fue detenido y desaparecido el 25 de agosto de 1974 por un retén militar en el Estado de Guerrero. Se trataba de un ex presidente municipal de Atoyak de Álvarez, a quien se lo había involucrado en la guerrilla. Por ese caso se responsabilizó en el 2005 a un alto jefe del ejército que fue llevado a la justicia militar, y en el 2006 se dispuso el cierre del mismo.

${ }^{16}$ Podemos citar, en concordancia con lo dicho: a) en el caso Rosendo Cantú y otra Vs. México (Supervisión de Cumplimiento de Sentencia, Resolución del 25 de noviembre de 2010), donde la Corte IDH, que había condenado a dicho país por la investigación insuficiente del delito de violación sexual, sostuvo que "...el Estado deberá conducir en el fuero ordinario, eficazmente y dentro de un plazo razonable, la investigación...", añadiendo que ese cuerpo supranacional seguirá supervisando, y b) en el caso Fernández Ortega y otros Vs. México (Supervisión de Cumplimiento de Sentencia, Resolución del 25 de noviembre de 2010), también por violación sexual, donde la Corte IDH llegó a la misma conclusión. Otro asunto de índole similar lo tenemos en el caso Comunidad Indigena Sawhoyamaxa Vs. Paraguay (Supervisión de Cumplimiento de Sentencia, Resolución del 20 de mayo de 2009), aquí el Estado pagó como indemnización más de 380.000 dólares (a cuenta) a los familiares de varias víctimas, que habitaban en el Chaco paraguayo, por violación de sus derechos fundamentales (por falta de atención estatal).

${ }^{17}$ Corte IDH, Caso Radilla Pacheco Vs. México, Supervisión de Cumplimiento de Sentencia, Resolución de la Corte Interamericana de Derechos Humanos 19 de mayo de 2011.

${ }_{18}$ Corte IDH, Caso Radilla Pacheco Vs. México. Supervisión de Cumplimiento de Sentencia (cit.). Resolución de 19 de mayo de 2011, párr. 58. 2. c), dijo allí que el país debía "adoptar, en un plazo razonable, las reformas legislativas pertinentes para compatibilizar el artículo 57 del Código de Justicia Militar con los estándares internacionales en la materia y con la Convención Americana sobre Derechos Humanos (punto resolutivo décimo y Considerandos 20 a 22)".

${ }^{19}$ Véase el libro de los autores Ferrer Mac-Gregor, Eduardo, Silva García, Fernando, El caso Castañeda Gutman ante la Corte Interamericana de Derechos Humanos", Editorial Porrúa México-Universidad Nacional Autónoma de México, año 2009; allí se estudia en profundidad el asunto de referencia.

${ }^{20}$ En su artículo 10 dispone: "En los Estados Unidos Mexicanos todas las personas gozarán de los derechos humanos reconocidos en esta Constitución y en los tratados internacionales de los que el 
A su vez la Suprema Corte de ese país al analizar el pronunciamiento condenatorio, aceptó el control difuso de "constitucionalidad" y de paso también la inspección difusa de "convencionalidad" 21 , siguiendo las pautas tenidas en cuenta en el voto Razonado del Juez ad-hoc Ferrer Mac-Gregor ${ }^{22}$ en el caso Cabrera García y Montiel Flores ${ }^{23}$.

En el caso Radilla Pacheco el Pleno de ese Tribunal determinó en definitiva que los integrantes de las fuerzas armadas que mancillen las garantías individuales de la población deben ser juzgados en el fuero común y no en el federal; y por ende no podrá intervenir la justicia castrense. Vale la pena tener presente que como corolario de todo esto la Corte doméstica decidió que la sentencia interamericana aludida es obligatoria para el Estado mexicano ${ }^{24}$. Lo cierto es que el Tribunal regional sigue supervisando el caso y en su pronunciamiento del 19 de mayo, dispuso no archivarlo por ahora ${ }^{25}$.

Estado Mexicano sea parte, así como de las garantías para su protección, cuyo ejercicio no podrá restringirse ni suspenderse, salvo en los casos y bajo las condiciones que esta Constitución establece [...] Las normas relativas a los derechos humanos se interpretarán de conformidad con esta Constitución y con los tratados internacionales de la materia favoreciendo en todo tiempo a las personas la protección más amplia [...] Todas las autoridades, en el ámbito de sus competencias, tienen la obligación de promover, respetar, proteger y garantizar los derechos humanos de conformidad con los principios de universalidad, interdependencia, indivisibilidad y progresividad. En consecuencia, el Estado deberá prevenir, investigar, sancionar y reparar las violaciones a los derechos humanos, en los términos que establezca la ley [...] Está prohibida la esclavitud en los Estados Unidos Mexicanos. Los esclavos del extranjero que entren al territorio nacional alcanzarán, por este solo hecho, su libertad y la protección de las leyes [...] Queda prohibida toda discriminación motivada por origen étnico o nacional, el género, la edad, las discapacidades, la condición social, las condiciones de salud, la religión, las opiniones, las preferencias sexuales, el estado civil o cualquier otra que atente contra la dignidad humana y tenga por objeto anular o menoscabar los derechos y libertades de las personas" (Constitución Política de los Estados Unidos Mexicanos de 5 de febrero de 1917, modificada el 10 de junio de 2011, publicada en el DOF el 10 de junio de 2011).

${ }^{21}$ De ello resulta -según lo entiendo- que ahora todos los jueces de México deben inspeccionar la compatibilidad de las leyes internas, con las de la $\mathrm{CADH}$ en los asuntos en los que están involucrados.

22 Además de las modificaciones a la Carta Magna, en junio de 2011, se aprobó otra reforma Constitucional en materia de amparo, de gran importancia, donde se incorpora la posibilidad de que las sentencias tengan efectos erga omnes, admitiendo los casos de interés legítimo, etc.

${ }^{23}$ Corte IDH, Caso Cabrera García y Montiel Flores Vs. México, Sentencia de 26 de noviembre de 2010, Serie C No 220.

${ }^{24}$ El propio gobierno reconoció la responsabilidad internacional del Estado. A través de un mensaje emitido el 2 de agosto de 2011, el Secretario de la Gobernación dijo “...que ese pronunciamiento da muestra de la clara apertura y transparencia con la que hoy se conduce el gobierno de México...".

${ }^{25}$ En el párr. 58.2, Resolutivos 1 y 2 decidió “...De conformidad con lo señalado en los considerandos pertinentes de la presente Resolución, se encuentran pendientes de cumplimiento los siguientes 
Enfocada esta problemática desde el punto de vista del Derecho Interno Mexicano no será baladí remarcar que el fallo local -tomado por siete votos contra tres-autorizó esa inspección de Constitucionalidad y Convencionalidad por parte de cualquier juez (control difuso) para asegurar que los magistrados judiciales no contradigan el sentido de las disposiciones del Pacto de San José de Costa Rica. Conviene aclarar que para que una decisión del Tribunal en pleno sea obligatoria se requieren ocho votos por lo menos ${ }^{26}$.

En suma, la Suprema Corte de dicho país el 14 de julio de 2011, al analizar el cumplimiento de la sentencia condenatoria de la Corte IDH (Radilla Pacheco), amplió la posibilidad de control por parte de los judicantes ${ }^{27}$.

Quedó en claro, en ese trascendente fallo, que la sentencia del Tribunal regional es obligatoria para México ${ }^{28} y$, por ende, debe ser cumplida ${ }^{29}$.

puntos resolutivos de la Sentencia: [...] Resuelve: 1. Requerir a los Estados Unidos Mexicanos que adopte todas las medidas que sean necesarias para dar efectivo y pronto acatamiento a los puntos pendientes de cumplimiento, señalados en el punto declarativo segundo supra, de conformidad con lo estipulado en el artículo 68.1 de la Convención Americana sobre Derechos Humanos. 2. Solicitar a los Estados Unidos Mexicanos que, a más tardar el 29 de agosto de 2011, presenten un informe detallado sobre las medidas adoptadas para cumplir con las reparaciones ordenadas que se encuentran pendientes de cumplimiento, en los términos establecidos en los Considerandos 7 a 56 de esta Resolución. Posteriormente, el Estado mexicano debe continuar presentando un informe de cumplimiento cada tres meses".

${ }^{26}$ En efecto la Ley Orgánica del Poder Judicial de la Federación menciona tal circunstancia. Con estos guarismos el pronunciamiento aludido tiene un gran valor como criterio orientador.

${ }^{27}$ Resolución del 14 de julio de 2011. El engrose se publicó el 4 de octubre de ese año, en el Diario Oficial de la Federación.

${ }^{28}$ Reiteramos que esta obligatoriedad no sólo rige para el Poder Judicial, sino para todas las autoridades del país en su ámbito de competencia (arts. 1.1 y 2 del Pacto de San José de Costa Rica). Debe tenerse en consideración que como ya lo expresamos, el art. $1^{\circ}$ de la Constitución reformada en el 2011 incorpora expresamente la problemática de los Derechos Humanos, pero a su vez el viejo artículo 133 -todavía vigente- dispone que "Esta Constitución, las leyes del Congreso de la Unión que emanen de ella y todos los Tratados que estén de acuerdo con la misma, celebrados y que se celebren por el Presidente de la República, con aprobación del Senado, serán la Ley Suprema de toda la Unión. Los jueces de cada Estado se arreglarán a dicha Constitución, leyes y tratados, a pesar de las disposiciones en contrario que pueda haber en las constituciones o leyes de los Estados".

${ }^{29}$ Véase el enjundioso trabajo de Eduardo Ferrer Mac-Gregor, Interpretación conforme y control difuso de convencionalidad. El nuevo paradigma para el Juez Mexicano", en Caabonel y Salazar (Coordinadores), Derechos Humanos: un nuevo modelo constitucional, México, UNAM, II.J., 2011, pp. 339-429. Ídem Ferrer Mac-Gregor, Eduardo, Coordinador, "Interpretación conforme y control difuso de convencionalidad. El nuevo paradigma para el juez mexicano", en "El control difuso de convencionalidad. Diálogo entre la Corte Interamericana de Derechos Humanos y los jueces nacionales", Fundap, México, 2012, p. 163. 
Como expresa Ferrer Mac-Gregor "la Suprema Corte de Justicia al decidir sobre el cumplimiento del caso Radilla Pacheco el 14 de julio de 2011 y que el propio Presidente de dicho Tribunal calificó como un asunto 'histórico', realizó interpretaciones constitucionales de gran calado para el sistema jurídico mexicano, apoyándose en gran medida en los nuevos contenidos normativos del vigente artículo $1^{\circ}$ constitucional. Los criterios principales que derivan de dicho asunto son los siguientes: a) Obligatoriedad de las sentencias condenatorias de la Corte IDH en los asuntos donde el Estado mexicano es parte; por lo que no pueden ser objeto de revisión por la Suprema Corte, ni siquiera cuando se trata de reservas o declaraciones interpretativas formuladas en su momento por el Estado mexicano; b) Obligaciones específicas a los jueces mexicanos (como parte del Estado mexicano) derivadas del cumplimiento de dichas sentencias; por lo que existen, en la sentencia del Caso Radilla, obligaciones para el Poder Judicial de la Federación y los jueces mexicanos, particularmente para la Suprema Corte, con independencia de las obligaciones a otros poderes y órganos del Estado mexicano; c) El deber de todos los jueces del Estado mexicano de ejercer el Control Difuso de Convencionalidad, ex officio, entre las normas internas y la $\mathrm{CADH}$, dentro de sus respectivas competencias y regulaciones procesales correspondientes" ${ }^{30}$.

Todas estas decisiones de los cuerpos supranacionales han servido, como dice Marcel Storme, para uniformar la jurisprudencia regional, tal cual sucedió en el viejo continente. Ha señalado con mucha claridad dicho autor que, a través de la interpretación hecha por el Tribunal del Tratado de Roma -con sede en Estrasburgo-, en especial del artículo 6 -similar al artículo 8 del Pacto de San José de Costa Rica-, más de ochocientos millones de habitantes pertenecientes al Consejo de Europa están bajo la influencia de ese Tribunal internacional ${ }^{31}$.

Por eso señalamos que en verdad el órgano judicial Interamericano ha jugado, en el campo doméstico, un papel que podríamos llamar "casatorio"32 (como unificador de la jurisprudencia), imponiendo indirectamente cierta

${ }^{30}$ Ferrer Mac-Gregor, Eduardo, "El control difuso de convencionalidad", ob. cit., p. 163.

${ }^{31}$ Véase Hitters, Juan C. y Fappiano, Óscar, Derecho Internacional de los Derechos Humanos, $2^{a}$ Edición, EDIAR, Buenos Aires, T. I, V. 2, pp. 656 y ss.

${ }^{32}$ En sentido lato. 
homogeneidad en la interpretación de la Convención y de otros tratados ${ }^{33}$; y -repetimos- viene supervisado inclusive el cumplimento de sus propios fallos ${ }^{34}$.

Debemos repetir que estos decisorios judiciales son obligatorios para los Estados en cada caso concreto ${ }^{35}$, de conformidad con los artículos 62.3 y 68 del Pacto de Costa Rica y la jurisprudencia del Tribunal regional que hemos citado $^{36}$.

Sin perjuicio de lo que antecede no hay que perder de vista que refiriéndose al derecho peruano el Tribunal regional ha expresado en el caso de La Cantuta que "De las normas y jurisprudencia de derecho interno analizadas, se concluye que las decisiones de esta Corte tienen efectos inmediatos y vinculantes y que, por ende, la sentencia dictada en el caso Barrios Altos está plenamente incorporada a nivel normativo interno. Si esta Sentencia fue determinante en lo allí dispuesto tiene efectos generales, esa declaración conforma ipso iure parte del derecho interno peruano, lo cual se refleja en las medidas y decisiones de los órganos estatales que han aplicado e interpretado esa Sentencia" ${ }^{37}$.

Por ende, importa parar mientes en que tanto en Barrios Altos, como en los casos Tribunal Constitucional de Perú y en La Cantuta, la Corte Interamericana se comportó como un Tribunal Constitucional anulando las leyes de amnistía, con efecto erga omnes. Obsérvese, entonces, cómo dicho órgano ha "amplificado" notablemente su tradicional postura, sosteniendo ahora que la obligatoriedad de sus pronunciamientos no se agota en su parte resolutiva (que vale para el caso particular), sino que se multiplica expansivamente (valga

\footnotetext{
${ }^{33}$ Véase, Albanese, Susana, Supervisión e incumplimiento de sentencias nacionales e internacionales. Problemas estructurales, JA, Fascículo 10-2005, pp. 3-17.

${ }^{34}$ Sostiene Morello que las Corte Supremas Nacionales no son ya instancia última y que la eventual revisión de sus pronunciamientos definitivos sucede en una instancia internacional (Morello, Augusto Mario, Estudios de Derecho Procesal, T. II, Abelardo Perrot, Buenos Aires, 1998, pp. 1209-1209).

35 Sobre los efectos de la sentencia en el Tribunal Europeo de Derechos Humanos, véase HitTers, Juan Carlos, Fappiano, Óscar, Derecho Internacional de los Derechos Humanos, ob. cit., T. I, V. 2, p. 709.

${ }^{36}$ Aunque por obvio no olvidemos que las Medidas Provisionales que dicta la Corte son también de cumplimiento obligatorio (doctrina de los artículos 11, 2, 63.2 y 68 de la CADH). Ese cuerpo ha puesto énfasis en señalar que el incumplimiento de estas puede general para el Estado una Responsabilidad Independiente respecto de la sentencia de fondo.

${ }^{37}$ Caso La Cantuta Vs. Perú (cit.), citando el caso Barrios Altos Vs. Perú (cit.). Dichas pautas fueron aplicadas por la CSN en varios casos entre los que podemos citar: Hagelin, Ranger (CSJN 1993/12/2), voto del Dr. Fayt, párr. 7, y voto del Dr. Boggiano, párr. 4.
} 
la redundancia), a los fundamentos del fallo, obligando a los tres poderes del Estado para la generalidad de los casos similares ${ }^{38}$.

Desde este cuadrante, ha puesto de relieve reiteradamente la Corte que la obligación de acatar sus fallos corresponde al principio básico del derecho de la responsabilidad internacional de los países ${ }^{39}$, apoyada en la jurisprudencia internacional, según la cual los Estados deben llevar a cabo sus obligaciones convencionales internacionales, de buena fe (pacta sunt servanda ${ }^{40}$.

Tal cual lo ha remarcado ese Tribunal y surge ${ }^{41}$ “...del artículo 27 de la Convención de Viena sobre el Derecho de los Tratados de 1969, los Estados no pueden por razones de orden interno dejar de atender la responsabilidad internacional ya establecida" (lo remarcado no está en el original ${ }^{42}$.

\section{B. Supervisión del cumplimiento.}

Como lo señalamos -reiteradamente-, la Corte IDH no sólo condena a los Estados cuando infrinjan los Tratados Internacionales pertinentes, sino que, además, en los últimos tiempos viene ejerciendo una importantísima labor, convirtiéndose en una especie de "juez de ejecución” de sus fallos, controlando y supervisando a rajatabla su acatamiento ${ }^{43}$.

\footnotetext{
${ }^{38}$ Hitters, Juan Carlos, ¿Son vinculantes los pronunciamientos de la Comisión y de la Corte Interamericana de Derechos Humanos? Control de constitucionalidad y convencionalidad, La Ley, 2008-E, pp. 1169 y siguientes.

39 Corte IDH, Caso Baena Ricardo y otros Vs. Panamá, Sentencia de 2 de febrero de 2001, Serie C No 72 .

${ }^{40} \mathrm{Ha}$ dicho la Corte IDH que la responsabilidad del país - por el principio de continuidad del Estado- se origina con independencia de la época en la que se cometieron las violaciones. Véase, Corte IDH, Caso Yvon Neptune Vs. Haití, Sentencia de 8 de mayo de 2008, Serie C No 180, párrs. 41 y siguientes.

${ }^{41}$ Corte IDH, Caso Liliana Ortega y otras, Medidas Provisionales respecto de Venezuela del 4 de mayo del 2004.

${ }^{42}$ Hitters, Juan Carlos, Responsabilidad del Estado por violación de Tratados Internacionales, Revista la Ley, Buenos Aires, 2007-C, p. 875. Ídem en Estudios Constitucionales, Revista Semestral del Centro de Estudios Constitucionales, Año 5 No 1, Universidad de Talca, Santiago de Chile, 2007, pp. 203-222. Sobre la responsabilidad del Estado por violación de los tratados internacionales. Véase el excelente libro de los juristas colombianos Ernesto Rey Cantor y Ángela Margarita Rey Amaya, Medidas provisionales $y$ medidas cautelares en el sistema interamericano de derechos humanos, IIDH, UNAM, México, Temis, Bogotá, Colombia, pp. 246 a 346.

43 Sobre esta problemática puede verse Carlos Ayala Corrao, "La ejecución de las sentencias de la Corte Interamericana de Derechos Humano en los Estados Constitucionales”, Universidad de Talca, Año 5, No 1, pp. 127 a 201.
} 
Efectivamente, el art. 69 de su nuevo Reglamento dice que dicho trámite se realizará mediante a) los informes a presentar por el Estado, b) las observaciones a los mismos hechas por la víctima o su representante, y c) las observaciones de la CIDH tanto a los informes estatales como a las consideraciones de la víctima o su representante (art. 69.1). Añade dicho precepto que sin perjuicio de ello, el Tribunal puede acudir a otras fuentes de información -incluidos peritajes e informes- que considere oportunos, requiriéndoles datos relevantes sobre el caso que permitan apreciar el cumplimiento (art. 69.2). De igual modo, a ese mismo objeto, está en condiciones de convocar al Estado y a los representantes de las víctimas a una audiencia, en la que escuchará la opinión de la Comisión (art. 69.3). Una vez que se considere suficientemente informada, la Corte determina el estado de cumplimiento de lo fallado y emite las resoluciones que considere pertinentes (art. 69.4).

Estas pautas se hacen extensivas a los casos que resultan promovidos por un Estado (demanda interestatal) (art. 69.5).

Conviene poner de resalto que antes de la aparición del art. 69 del citado Reglamento (Aprobado por la Corte en su LXXXV Período Ordinario de Sesiones celebrado del 16 al 28 de noviembre de 2009), la Corte venía fijando el criterio de que le correspondía la supervisión de sus Resoluciones y que sólo se archivarían cuando el pronunciamiento estuviera totalmente acatado.

Efectivamente, en el caso Baena Vs. Panamá ${ }^{44}$ el demandado discutió esta potestad del Tribunal Interamericano y planteó una cuestión de competencia; dijo en ese sentido el Estado panameño que "...la etapa de Supervisión de Cumplimiento de Sentencias es una etapa pos adjuticativa que no está prevista por las normas que regulan la jurisdicción y el procedimiento de la honorable Corte" 45 .

En dicho asunto ese cuerpo judicial le respondió con muy buen tino que "...La jurisdicción comprende la facultad de administrar justicia; no se limita a declarar el derecho, sino que también comprende la supervisión del cumplimiento de lo juzgado. Es por ello necesario establecer y poner en funcionamiento mecanismos o procedimientos para la supervisión del cumplimiento de las decisiones judiciales, actividad que es inherente a la función jurisdiccional. La supervisión del cumplimiento de las sentencias es uno de

${ }^{44}$ Corte IDH, Caso Baena Ricardo y otros Vs. Panamá. Competencia. Sentencia de 28 de noviembre de 2003. Serie C No 104.

${ }^{45}$ Corte IDH, Caso Baena Ricardo y otros Vs. Panamá, (cit.), párr. 26. 
los elementos que componen la jurisdicción. Sostener lo contrario significaría afirmar que las sentencias emitidas por la Corte son meramente declarativas y no efectivas. El cumplimiento de las reparaciones ordenadas por el Tribunal en sus decisiones es la materialización de la justicia para el caso concreto y, por ende, de la jurisdicción; en caso contrario se estaría atentando contra la raison d'être de la operación del Tribunal [...] La efectividad de las sentencias depende de su ejecución. El proceso debe tender a la materialización de la protección del derecho reconocido en el pronunciamiento judicial mediante la aplicación idónea de dicho pronunciamiento" ${ }^{46}$. Añadió que la ejecución de tales decisiones y sentencias debe ser vista como parte integrante del derecho de acceso a la justicia, entendiéndolo en sentido amplio, que abarque también el cumplimiento pleno de la providencia pertinente ${ }^{47}$.

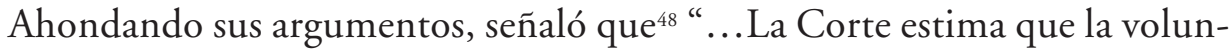
tad de los Estados, al aprobar lo estipulado en el artículo 65 de la Convención, fue otorgar a la misma Corte la facultad de supervisar el cumplimiento de sus decisiones, y que fuera el Tribunal el encargado de poner en conocimiento de la Asamblea General de la OEA, a través de su Informe Anual, los casos en los cuales se diera un incumplimiento de las decisiones de la Corte, porque no es posible dar aplicación al artículo 65 de la Convención sin que el Tribunal supervise la observancia de sus decisiones..." 49.

Finalmente, y como anticipándose a la redacción del artículo 69, el Tribunal ya había dicho en el mencionado caso que era conveniente fijar estas pautas en una norma reglamentaria dentro de las reglas de procedimiento.

${ }^{46}$ Corte IDH, Caso Baena Ricardo y otros Vs. Panamá, (cit.), párrs. 72 y 73.

${ }^{47}$ Corte IDH, Caso Baena Ricardo y otros Vs. Panamá, (cit.), párr. 82.

${ }^{48}$ Corte IDH, Caso Baena Ricardo y otros Vs. Panamá, (cit.), párr. 90.

${ }^{49}$ Ahondando sus argumentaciones, puso se relieve que "Por otro lado, la facultad de la Corte para supervisar el cumplimiento de sus sentencias y el procedimiento adoptado para ello también encuentra su fundamento en la práctica constante y uniforme de la Corte y en la resultante opinio juris communis de los Estados Partes en la Convención, respecto de los cuales la Corte ha emitido diversas resoluciones sobre cumplimiento de sentencia. La opinio juris communis significa la manifestación de la conciencia jurídica universal $[\ldots]$ a través de la observancia, por la generalidad de los miembros de la comunidad internacional, de una determinada práctica como obligatoria [...] La referida opinio juris communis se ha manifestado en que dichos Estados han mostrado una actitud generalizada y reiterada de aceptación de la función supervisora de la Corte, lo cual se ha visto clara y ampliamente demostrado con la presentación por parte de éstos de los informes que la Corte les ha solicitado, así como con la observancia de lo resuelto por el Tribunal al impartirles instrucciones o dilucidar aspectos sobre los cuales existía controversia entre las partes, relativos al cumplimiento de las reparaciones" (Corte IDH, Caso Baena Ricardo y otros Vs. Panamá, [cit.], párr. 102). 
Parece de Perogrullo reiterar que -como quedó dicho- los argumentos expuestos por la Corte en el caso Baen $a^{50}$, fueron plasmados en el referido art. 69 del Reglamento, en su actual redacción ${ }^{51}$.

Adviértase que hasta principios de 2011 el aludido ente jurisdiccional tiene en Supervisión del Cumplimiento una gran cantidad de asuntos, que - por ende- no se encuentran concluidos ni cerrados, según lo ha informado el propio Tribunal ${ }^{52}$.

Con respecto a la República Argentina, la Corte ha condenado a este país en once $\operatorname{casos}^{53}$, de los cuales seis de ellos están siendo supervisados por el aludido Tribunal interamericano ${ }^{54}$.

${ }^{50}$ Finalmente, como antes vimos, el referido artículo quedó redactado del siguiente modo: "Artículo 69. Supervisión de cumplimiento de sentencias y otras decisiones del Tribunal: 1. La supervisión de las sentencias y demás decisiones de la Corte se realizará mediante la presentación de informes estatales y de las correspondientes observaciones a dichos informes por parte de las víctimas o sus representantes. La Comisión deberá presentar observaciones al informe del Estado y a las observaciones de las víctimas o sus representantes. 2. La Corte podrá requerir a otras fuentes de información datos relevantes sobre el caso, que permitan apreciar el cumplimiento. Para los mismos efectos podrá también requerir los peritajes e informes que considere oportunos. 3. Cuando lo considere pertinente, el Tribunal podrá convocar al Estado y a los representantes de las víctimas a una audiencia para supervisar el cumplimiento de sus decisiones, y en ésta escuchará el parecer de la Comisión. 4. Una vez que el Tribunal cuente con la información pertinente, determinará el estado del cumplimiento de lo resuelto y emitirá las resoluciones que estime pertinentes. 5. Estas disposiciones se aplican también para casos no sometidos por la Comisión", (Reglamento de la Corte Interamericana de Derechos Humanos, Aprobado por la Corte en su LXXXV Período Ordinario de Sesiones, celebrado del 16 al 28 de noviembre de 2009).

${ }^{51}$ Hay que tomar en consideración que la ejecución y supervisión de las sentencias de la Corte IDH, en la realidad, implican una "doble victimización" para el damnificado, pues luego de un largo "pleito" ante el Tribunal Interamericano, tiene que padecer un nuevo trámite para llegar al acatamiento. Además vale la pena alertar que los Estados tardan mucho en girar el informe del art. 69, por lo que sería conveniente que en el futuro se disponga un plazo perentorio para que los países eleven dicha información al Tribunal.

52 Ver http://www.corteidh.or.cr/supervision.cfm

${ }^{53}$ Corte IDH. Caso Maqueda Vs. Argentina. Excepciones Preliminares. Resolución de 17 de enero de 1995. Serie C No 18; Corte IDH. Caso Garrido y Baigorria Vs. Argentina. Fondo. Sentencia de 2 de febrero de 1996. Serie C No 26; Corte IDH. Caso Garrido y Baigorria Vs. Argentina. Reparaciones y Costas. Sentencia de 27 de agosto de 1998. Serie C No 39; Corte IDH. Caso Cantos Vs. Argentina. Excepciones Preliminares. Sentencia de 7 de septiembre de 2001. Serie C No 85; Corte IDH. Caso Cantos Vs. Argentina. Fondo, Reparaciones y Costas. Sentencia de 28 de noviembre de 2002. Serie C No 97; Corte IDH. Caso Bulacio Vs. Argentina. Fondo, Reparaciones y Costas. Sentencia de 18 de "septiembre de 2003. Serie C No 100; Corte IDH. Caso Bueno Alves Vs. Argentina. Fondo, Reparaciones y Costas. Sentencia de 11 de mayo de 2007. Serie C No 164; Corte IDH. Caso Kimel Vs. Argentina. 
No debemos perder de vista que el Tribunal regional resuelve en los últimos tiempos aproximadamente un promedio de 20 sentencias de fondo por año habida cuenta que en su actual estructura no le permite elevar fácilmente esos guarismos.

Por ello es importante que los Estados sepan acatar no sólo las decisiones en los asuntos concretos en los que resultan condenados, sino como antes vimos, deberían tener en cuenta la doctrina legal que se infiere de los fallos en casos similares.

Actualmente y para consolidar estas pautas la Corte lleva a cabo lo que podríamos definir como supervisiones temáticas, por ejemplo, la problemática del 'derecho a la salud' (Colombia) o la atinente a la 'posición y propiedad de tierras' (Paraguay).

También apunta a dar soluciones estruturales, esto es, a través de un caso fijar criterios válidos para otros asuntos de idéntica naturaleza.

Para desahogar a ese cuerpo, en los últimos tiempos algún país ha reconocido su responsabilidad internacional antes de la condena, como ha sucedido en la Argentina, por ejemplo.

\section{Cláusula Federal}

\section{A. Cláusula federal (Federalismo y división de Poderes)}

Interesa saber cómo manejan los Estados Federales el cumplimiento de las sentencias cuando las infracciones han sido cometidas en sus Provincias o Estados locales.

Dispone la CADH: "Artículo 28. Cláusula Federal. 1. Cuando se trate de un Estado parte constituido como Estado Federal, el gobierno nacional de dicho Estado parte cumplirá todas las disposiciones de la presente Convención relacionadas con las materias sobre las que ejerce jurisdicción legislativa y judicial. 2. Con respecto a las disposiciones relativas a las materias que corresponden a la jurisdicción de las entidades componentes de la federación, el gobierno nacional debe tomar de inmediato las medidas pertinentes, conforme a su

Fondo, Reparaciones y Costas. Sentencia de 2 de mayo de 2008 Serie C No 177; Corte IDH. Caso Bayarri Vs. Argentina. Excepción Preliminar, Fondo, Reparaciones y Costas. Sentencia de 30 de octubre de 2008. Serie C No 187 (ver http://www.corteidh.or.cr/pais.cfm?id_Pais=2).

${ }^{54}$ Ver http://www.corteidh.or.cr/pais.cfm?id_Pais=2. 
constitución y sus leyes, a fin de que las autoridades competentes de dichas entidades puedan adoptar las disposiciones del caso para el cumplimiento de esta Convención. 3. Cuando dos o más Estados Partes acuerden integrar entre sí una federación u otra clase de asociación, cuidarán de que el pacto comunitario correspondiente contenga las disposiciones necesarias para que continúen haciéndose efectivas en el nuevo Estado así organizado, las normas de la presente Convención".

Dicha norma ha tenido como fuente el artículo 50 del Pacto Internacional de Derechos Civiles y Políticos de las Naciones Unidas, que dispone: "Las disposiciones del presente Pacto serán aplicables a todas las partes componentes de los Estados Federales, sin limitación ni excepción alguna”.

Lo cierto es que desde esa vertiente hay que tener en cuenta que la estructura federal de algunos de los países adheridos al modelo del Pacto de San José repercute notoriamente tanto en el sistema internacional como en el doméstico. Resulta por demás sabido que, cuando los agentes públicos responsables de las violaciones dependen de las autoridades locales, el gobierno central se encuentra en situaciones difíciles al momento de acatar a cabalidad las decisiones de la Corte IDH ${ }^{55}$.

En la Argentina ha habido varias violaciones de la Convención por las que resultó condenado el país; siendo que en algunos casos tales infracciones fueron originadas en algunas provincias.

Analizando el artículo 28 antes citado, podemos llegar a una primera conclusión: que el Pacto de San José establece como deber fundamental de los países -sean unitarios o federales- el respeto a los derechos y garantías que surgen de la Convención. En efecto, el artículo 1.1 indica que los Estados Partes “....se comprometen a respetar los derechos y garantías reconocidos en ella y a garantizar su libre y pleno ejercicio, a toda persona que esté sujeta a su jurisdicción...". A su vez el artículo 2 dispone que "si el ejercicio de los derechos y libertades mencionados en el artículo 1 no estuviere ya garantizado por disposiciones legislativas o de otro carácter, los Estados se comprometen a adoptar las me-

\footnotetext{
55 Dulitzky, Ariel, Federalismo y Derechos Humanos. El caso de la Convención Americana sobre Derechos Humanos y la República Argentina, en Anuario Mexicano de Derecho Internacional, Volumen VI, 2006, p. 201. Véase también, mismo autor, La Convención Americana sobre Derechos Humanos y los Estados Federales: algunas reflexiones, en BAZÁN, Víctor, Coordinador, Defensa de la Constitución. Galantismo y controles, libro en reconocimiento al Dr. Germán Bidart Campos, EDIAR, Buenos Aires, 2003, p. 157.
} 
didas legislativas o de otro carácter que fueran necesarias para hacer efectivos tales derechos y libertades" 56 . Si Argentina no cumple con dichos dispositivos normativos incurre en responsabilidad internacional ${ }^{57}$.

De la interpretación armónica de los artículos 1.1, 2, 28 y 68 de la CADH, se infiere sin dudas que los habitantes de cualquiera de las Provincias o de la propia Ciudad Autónoma de Buenos Aires están sometidos al sistema del Pacto, y que cualquier infracción de ellos puede generar la responsabilidad del Estado Nacional.

Para dotar al gobierno central de mayor eficiencia, se ha "federalizado" en algunas situaciones la persecución de los delitos vinculados con los derechos humanos que surgen de los Tratados internacionales, y un claro ejemplo argentino es el caso Verbitsky, que luego analizaremos ${ }^{58}$.

\section{B. Nación y Provincias (o Estados Federales). \\ Deslinde de competencias}

Es dable repetir que el artículo 28 de la Convención sirve para deslindar responsabilidades en las distintas jurisdicciones en el ámbito doméstico, pero nunca para eximir al Estado Federal del cumplimiento de las sentencias condenatorias $^{59}$.

\footnotetext{
${ }^{56}$ Véase Hitters, Juan Carlos, Responsabilidad del Estado por violación de Tratados Internacionales, cit., p. 875 .

${ }^{57}$ Corte IDH, Caso Almonacid Arellano y otros Vs. Chile, Sentencia de 26 de septiembre de 2006, Serie C No 154; Caso Instituto de Reeducación del Menor, Sentencia de 2 de septiembre de 2004, Serie C No 112, nota 135; ídem Caso Bulacio, Sentencia de 18 de septiembre de 2003, Serie C No 100, párr. 205; Conf. Caso Almonacid Arrellano (cit.), nota 6, párr. 118; Caso Ximenes Lopes Vs. Brasil, Sentencia de 4 de julio de 2006, Serie C No 149, nota 6, párr. 83, y Caso "La Última Tentación de Cristo" (cit.), párr. 85; Caso de "La Última Tentación de Cristo" Vs. Chile, Sentencia de 5 de febrero de 2001, Serie C, No 73 .

${ }^{58}$ Dulitzky, Ariel, Federalismo y Derechos Humanos..., ob. cit., pp. 211 y 212. Así por ejemplo Brasil, en una reciente reforma de su Carta Magna Nacional, dispone en su artículo 109 que "corresponde a los Jueces Federales: atender las causas relativas a los derechos humanos. En las hipótesis de graves violaciones, el Procurador General de la República, con al finalidad de asegurar el cumplimiento de las obligaciones emergentes de los Tratados internacionales de derechos humanos de los que Brasil sea parte, podrá suscitar, ante el Superior Tribunal de Justicia, en cualquier fase de la investigación o del proceso, incidente de transferencia de competencia para la Justicia Federal" (Enmienda Constitucional No 45/2004).

${ }^{59}$ Dulitzky, Ariel, Federalismo y Derechos Humanos..., ob. cit., nota 46, citando a Pinto, Mónica, Temas de derechos humanos, Editores del Puerto, Buenos Aires, 1997, p. 74.
} 
Debemos ver con detenimiento en qué grado de responsabilidad incurren las provincias, en el caso de la Argentina, por el incumplimiento de los Tratados y de las sentencias de la Corte IDH. En puridad de verdad, como lo pone de relieve Bidart Campos ${ }^{60}$, éstas no tienen responsabilidad jurídica internacional y por ende no forman parte del Pacto de San José ${ }^{1}$, lo que no significa que queden exentas de las eventuales consecuencias, en caso de falta de acatamiento.

En este aspecto téngase presente que de los artículos 5 y 31 de la Constitución Nacional se infiere sin vacilación alguna que si bien cada una de ellas puede dictar su propia Constitución, lo debe hacer siempre bajo el sistema representativo, republicano y de acuerdo con los principios, declaraciones y garantías de la Constitución (art. 5). Cuando la Carta Magna enuncia los principios de la Supremacía Constitucional, su artículo 31 reitera que la Constitución Federal, y las leyes que en su consecuencia dicte el Poder Legislativo, y los Tratados internacionales son la ley suprema de la Nación; y todo este bloque, denominado "ordenamiento federal" (o "derecho federal") prevalece sobre los esquemas locales (conf. artículo 75 inciso 22 de la Constitución reformada en 1994$)^{62}$.

A su vez, su artículo 128 pone de relieve "que los Gobernadores de provincia son agentes naturales del Gobierno Federal para cumplir la Constitución y las Leyes de la Nación”. Por ende el incumplimiento reiterado de alguna provincia podría generar -en casos de extrema gravedad- hasta la intervención federal de la misma (art. 6 de la Constitución Nacional)

Bajo esta visión parece claro que ante una condena por un hecho acaecido en el ámbito provincial, si el estado federal no actúa queda él como responsable internacionalmente.

Repárese que si la condena de la Corte IDH manda a pagar una suma de dinero (art. 68.2), la cosa resulta algo sencilla, ya que el gobierno central podría abonarla y luego repetir de alguna manera contra la provincia infractora.

${ }^{60}$ Bidart Campos, Germán, Tratado elemental de Derecho Constitucional Argentino, EDIAR, Buenos Aires, 1989.

${ }^{61}$ Bidart Campos, Germán, Tratado elemental..., Tomo I, ob. cit., pp. 279 y 320.

62 Bidart Campos, Germán, Tratado elemental..., Tomo I, ob. cit, p. 153. 


\section{Cuestiones Federales. El deslinde de las competencias y la jurisprudencia de la Corte Suprema de la Nación}

Desde antiguo nuestro más Alto Tribunal viene sosteniendo que lo referente a la interpretación de los Tratados internacionales implica una "cuestión federal' ${ }^{\prime 3}$ que tolera el recurso extraordinario del artículo 14 de la Ley $\mathrm{No}^{\circ} 48^{64}$. No hace mucho tiempo, ratificando esos conceptos ${ }^{65}$, expresó que "corresponde a la Corte Suprema de Justicia de la Nación, como cabeza de uno de los poderes del Gobierno Federal, en la medida de su jurisdicción, aplicar los Tratados internacionales a que el país está vinculado (...) a fin de evitar que la responsabilidad internacional de la República quede comprometida por su incumplimiento" 66 .

Un asunto paradigmático para elucidar la problemática que venimos abordando es -tal cual lo adelantamos- el caso Verbitsky ${ }^{67}$. Juzgó allí por

\footnotetext{
${ }^{63}$ Reiteradamente ha expresado que "los agravios traídos por la parte recurrente han planteado una cuestión federal que hace procedente el recurso deducido, toda vez que se ha puesto en tela de juicio la inteligencia de las normas de un tratado internacional enumerado en el art. 75 inc. 22 de la Constitución Nacional (Convención sobre los Derechos del Niño, art. 3.1), tal como ella ha sido interpretada por la jurisprudencia de este Tribunal y la sentencia del Superior Tribunal de la causa es contraria al derecho que el recurrente funda en ella (art. 14.3 de la Ley No 48)", in re M.D.H. c/ M.B.M.F., del 29/04/08, voto del Dr. Zaffaroni.

${ }^{64}$ Bidart Campos, Germán, Tratado elemental..., Tomo II, ob. cit., p. 464.

${ }^{65}$ CSJN, B., S. M. c/ P., B.A., del 19/05/2010, conf. Fallos 318:1269.

${ }^{66}$ En este sentido, ha dicho con anterioridad ese Tribunal que "...Lo dispuesto en los tratados internacionales que tienen jerarquía constitucional -art. 75, inc. 22, de la Ley Suprema- reafirma el derecho a la preservación de la salud -comprendido dentro del derecho a la vida- y destaca la obligación impostergable de la autoridad pública de garantizar ese derecho con acciones positivas, sin perjuicio de las obligaciones que deben asumir en su cumplimiento las jurisdicciones locales, las obras sociales o las entidades de medicina prepaga. (del dictamen de la Procuradora Fiscal subrogante que la Corte, por mayoría, hace suyo) [...] Resulta evidente la función rectora que ejerce el Estado Nacional en el campo de la salud y la labor que compete al Ministerio de Salud y Acción Social, como autoridad de aplicación, para garantizar la regularidad de los tratamientos sanitarios coordinando sus acciones con las obras sociales y los estados provinciales, sin mengua de la organización federal y descentralizada que corresponda para llevar a cabo tales servicios (del Dictamen de la Procuradora Fiscal subrogante que la Corte, por mayoría, hace suyo) [...] Existe cuestión federal, a los fines de la procedencia del recurso extraordinario, si se cuestiona la interpretación de leyes nacionales -Ley No 24.901, decreto 1606/2002- y la decisión ha sido contra la validez del derecho que es materia de litigio y se funda en dichas normas -art. 14, inc. $3^{\circ}$, de la Ley No 48-. (del dictamen de la Procuradora Fiscal subrogante que la Corte, por mayoría, hace suyo)". Corte Suprema de Justicia de la Nación, 18/09/2007, "Passero de Barriera, Graciela N. c/ Estado Nacional", Publicado Revista La Ley, 03/10/2007, 11-DJ2007III, p. 392, Cita online: AR/JUR/4946/2007.
}

${ }^{67}$ CSJN, Verbitsky, Horacio s/ hábeas corpus, V. 856. XXXVIII. 
mayoría la Corte Argentina -algo que ya había dicho- que las normas de los Tratados internacionales son obligatorias en todo el país y por lo tanto no pueden ser infringidas por las provincias. Para sostener este postulado, usó como pauta de referencia las Reglas Mínimas para el Tratamiento de Reclusos de las Naciones Unidas, a las que si bien no les reconoció jerarquía constitucional, entendió que a través del artículo 18 de la Carta Magna, se han convertido en un estándar internacional ${ }^{68}$ respecto de las personas privadas de su libertad ${ }^{69}$.

${ }^{68}$ Dulitzky, Ariel, Federalismo y Derechos Humanos..., ob. cit., p. 234.

${ }_{69}$ Dijo allí el Tribunal: "Que tanto en materia procesal penal como de ejecución penal se plantea la cuestión de la competencia legislativa. Si bien no cabe duda de que los códigos procesales son materia de legislación provincial en función de la cláusula residual, la existencia de disposiciones procesales en el Código Penal y la facultad del Congreso Nacional para dictar las leyes que requiera el establecimiento del juicio por jurados, parecen indicar que el Estado Federal ejerce cierto grado de legislación y orientación en materia procesal, con el fin de lograr un mínimo equilibrio legislativo que garantice un estándar de igualdad ante la ley" (párr. 55); "Que si bien la Constitución Nacional adopta el principio federal, lo hace según lo establece la presente Constitución, es decir, conforme a las modificaciones que la misma introduce respecto de su modelo, que era el norteamericano. Puesto que el federalismo argentino no tiene el mismo origen histórico que el norteamericano, pues procede de un régimen de descentralización administrativa que regía en la colonia, la distribución de competencia legislativa no es idéntica y las provincias delegan en el Estado Federal materias que se reservan en la Constitución de los Estados Unidos. En 1853 y en especial en la fuente norteamericana tomada con preferencia, no se conocían modelos constitucionales de facultades concurrentes en forma de leyes marco, como sucede contemporáneamente" (párr. 56), "Que respecto de la prisión preventiva, cualquiera sea la tesis que se adopte acerca de su naturaleza, lo cierto es que importa en la realidad un contenido penoso irreparable, lo que lleva a asimilar las controversias a su respecto a casos de sentencia definitiva, según inveterada jurisprudencia de esta Corte. Cualquiera sea el sistema procesal de una provincia y sin desmedro de reconocer su amplia autonomía legislativa en la materia, lo cierto es que si bien no puede llevarse la simetría legislativa hasta el extremo de exigir una completa igualdad para todos los procesados del país, la desigualdad tampoco puede extremar las situaciones hasta hacer que el principio federal cancele por completo el derecho a la igualdad ante la ley, pues un principio constitucional no puede borrar o eliminar otro de igual jerarquía. Una asimetría total en cuanto a la legislación procesal penal destruiría la necesaria unidad en materia penal que se mantiene en todo el territorio en virtud de un único Código Penal. Partiendo de la conocida afirmación de Ernst von Beling, de que el derecho penal no toca un solo pelo al delincuente, es sabido que incumbe al derecho procesal penal tocarle toda la cabellera y, por ello, se debe entender que, sin pretensión de cancelar las asimetrías, para la prisión preventiva -que es donde más incidencia represiva tiene el derecho procesal penal- las provincias se hallan sometidas a un piso mínimo determinado por los estándares internacionales a los que se ajusta la legislación nacional. No es lo mismo que, habiendo dos imputados en igualdad de condiciones y por el mismo delito, uno llegue al juicio libre y otro lo haga después de muchos meses o años de prisión, sin que el Estado Federal se asegure de que en el último caso, al menos, se respeta un piso mínimo común para todo el territorio. Por lo demás, no puede soslayarse, que en esta materia la legislación procesal nacional, receptaría las distintas disposiciones 
Surge con claridad del mencionado fallo que la legislación provincial podría ser inconstitucional en la medida que sea incompatible con una norma internacional (Considerando 58). Por ello la Corte Nacional ordenó a las autoridades bonaerenses el cumplimiento de un conjunto de medidas a los efectos de "adecuar” su legislación y su práctica a estándares supranacionales (art. 1.1 y 2 de la $\mathrm{CADH}$ ).

Del análisis somero que hemos hecho de la jurisprudencia del más Alto órgano de Justicia Argentino puede inferirse:

a) Que el gobierno central es responsable de asegurar y cumplir las obligaciones que nacen en los Tratados internacionales.

b) Que estas situaciones implican una "cuestión federal" que habilita la competencia de ese órgano jurisdiccional por vía del recurso extraordinario del artículo 14 de la Ley No 48, en especial cuando el incumplimiento se haya producido en una provincia.

c) Que los Estados provinciales deben acomodar su actuación a los Tratados internacionales.

d) Que el Estado Nacional no puede eximirse de ejecutar sus obligaciones metanacionales aduciendo la falta de acatamiento de las autoridades provinciales.

Sin perjuicio de lo que más adelante veremos, puede quedar como fondo común que en las provincias las personas afectadas por la falta de acatamiento de los Tratados internacionales pueden utilizar el remedio federal a fin de modificar tal situación ante la Corte Federal.

\section{MODALIDADES DE CUMPLIMIENTO DE LAS SENTENCIAS DE LA CORTE IDH EN EL DERECHO INTERNO}

\section{A. Modalidad de recepción}

Lo cierto es que en este país no existe -ya lo hemos dicho- un mecanismo institucional regulado que permita el necesario diálogo entre el gobierno nacional y las provincias, en lo que tiene que ver con el cumplimiento de los fallos

establecidas en el derecho internacional de los derechos humanos que forma parte de nuestro bloque constitucional federal" (párr. 57); "Que conforme a lo señalado en el considerando anterior, cabría analizar la eventual constitucionalidad de la legislación vigente en la Provincia de Buenos Aires en materia excarcelatoria, que prima facie parece alejarse del estándar trazado por el derecho internacional y que sigue la legislación nacional..." (párr. 58). 
de la Corte IDH y tambien de los Tratados Internacionales sobre Derechos Humanos.

Actualmente, conforme a la Ley de Ministerios 22.250 (t.o. 1992 y modificatoria), corresponde a la Dirección de Conserjería Legal del Ministerio de Relaciones Exteriores, Comercio Internacional y Culto, como a la Subsecretaría de Protección de los Derechos Humanos del Ministerio de Justicia y de Derechos Humanos, intervenir en las peticiones y casos que tramitan ante los organismos internacionales de derechos humanos. De ahí que ambas agencias trabajan de consuno en el seguimiento de los asuntos pertinentes ejerciendo la representación del Estado Argentino, el que a través del Poder Ejecutivo Nacional propone generalmente un espacio de diálogo con las víctimas de las violaciones, aún antes de que estas promuevan las vías pertinentes. Utiliza en la medida de las posibilidades la "solución amistosa" y también, cuando corresponde, el "reconocimiento de la responsabilidad internacional del país"70.

\section{B. Supervisión de cumplimiento. Casos Argentinos en supervisión.}

Actualmente en la Corte IDH tramitan los siguientes asuntos Argentinos, cuyo cumplimiento es supervisado por dicho organismo internacional ${ }^{71}$ :

\footnotetext{
${ }^{70}$ Podemos consignar algunas estadísticas - de fines del año 2010- de casos ante el sistema regional: Comisión Interamericana de Derechos Humanos (CIDH): Peticiones sin admisibilidad: 162, Casos con admisibilidad: 41, Medidas cautelares dictadas: 4, Solicitudes de medidas cautelares: 22, Casos con informe de fondo: 3. Porcentajes por Jurisdicción: Nación 44\%, Provincias 66\%: Buenos Aires 20\%, Mendoza 5\%, Resto de las Provincias (Con excepción de Catamarca que no registra denuncias en contra): $41 \%$. Corte Interamericana de Derechos Humanos (CORTE IDH): Casos en trámite: 6, Casos en supervisión de cumplimiento de sentencia: 7. Otros Países: En CIDH: Perú: 191 casos, Colombia 235 casos, México: 267 casos. En Corte IDH: Perú 27 casos, Guatemala 15 casos, Venezuela 14 casos, Colombia 12 casos.

Es de destacarse que los casos que se ventilan contra los países recién mencionados son política y jurídicamente más sensibles que los casos contra nuestro país.

Análisis cualitativo: Por hechos ocurridos antes de 2003: en CIDH 115 (aprox.), en Corte IDH 5. Por hechos ocurridos después del 2003: en CIDH 110 (aprox.), en Corte IDH 1 (3 de octubre de 2003). El 100\% de los casos incluyen denuncias de agravios por administración de justicia (arts. 8 y 25 de la Convención Americana).

A diferencia de otros países de la región, no se registran denuncias por violaciones masivas y sistemáticas de los derechos humanos.

Registros Públicos de la CIDH, www.cidh.oas.org y la Corte IDH, www.corteidh.or.cr.

${ }^{71}$ Sobre este tema puede verse Susana Albanese, Nuevas demandas ante la Corte IDH contra Argentina, en JA, Fascículo 12, 2011-III, p. 20.
} 


\section{Caso Bayarri Vs. Argentina. Supervisión de Cumplimiento de Sentencia. Resolución de la Corte Interamericana de Derechos Humanos de 22 de noviembre de 2010}

La Comisión pasó a la Corte el citado asunto el día 12 de enero de 2001, la que dictó sentencia el 30 de octubre de $2008^{72}$. Se trataba de la detención de Juan Carlos Bayarri a raíz de una confesión bajo tortura. El 25 de julio de 2005 la Sala Séptima de la Cámara Nacional de Apelaciones en lo Criminal y Correccional lo absolvió y ordenó su libertad.

En efecto, el 22 de noviembre de 2010 la Corte IDH inició el procedimiento de supervisión de la sentencia disponiendo que el Estado cumplió parcialmente la decisión del Tribunal Regional del 30 de noviembre de 2008, pero faltó terminar el procedimiento penal tendiente a investigar a los responsables de las torturas contra el señor Bayarri.

Éste había sido apresado en 1991 en la Provincia de Buenos Aires (en la Ciudad de Avellaneda) sin orden de detención. Fue torturado y en noviembre de 2010 cuando la Corte IDH inició el proceso de Supervisión todavía no se había castigado a los responsables de las torturas, obligación que le había impuesto dicho Tribunal en su mentado fallo del 30 de noviembre de 2008. Lo cierto es que el 25 de septiembre de 2010 la Cámara Nacional de Casación Penal anuló los sobreseimientos dictados en la causa y dispuso la

\footnotetext{
${ }^{72}$ La Corte IDH dispuso que: "[...] 8. El Estado debe pagar al señor Juan Carlos Bayarri las cantidades fijadas en los párrafos 141, 142, 151, 155, 159, 170 y 194 de la [...] Sentencia, por concepto de indemnización por daño material e inmaterial, y el reintegro de costas y gastos, dentro del plazo de un año, contado a partir de la notificación del [...] Fallo [...]. 9. El Estado debe brindar gratuitamente, de forma inmediata y por el tiempo que sea necesario, el tratamiento médico requerido por el señor Juan Carlos Bayarri [...]. 10. El Estado debe concluir el procedimiento penal iniciado por los hechos que generaron las violaciones del presente caso y resolverlo en los términos que la ley prevea [...]. 11. El Estado debe publicar en el Diario Oficial y en otros dos diarios de amplia circulación nacional, por una sola vez, los capítulos I, VII, VIII y IX de la [...] Sentencia, sin las notas al pie de página correspondientes, y la parte resolutiva de la misma, en el plazo de seis meses, contado a partir de la notificación del [...] Fallo [...]. 12. El Estado debe asegurar la eliminación inmediata del nombre del señor Juan Carlos Bayarri de todos los registros públicos con los que aparezca con antecedentes penales [...]. 13. El Estado debe incorporar, en la medida en que no lo haya hecho, a los miembros de las fuerzas de seguridad, de los órganos de investigación y de la administración de justicia en las actividades de difusión y formación sobre la prevención de la tortura y los tratos o penas crueles, inhumanos o degradantes [...]", (Corte IDH, Caso Bayarri Vs. Argentina, Supervisión de Cumplimiento de Sentencia, Resolución de la Corte Interamericana de Derechos Humanos 22 de noviembre de 2010).
} 
continuación del proceso criminal para que continúe la investigación y la condena a los responsables.

Sintetizando este asunto, cabe destacar que el Estado ha acatado en parte la condena aunque ciertos tópicos todavía no han sido concluidos en su totalidad. Por ello, con muy buen tino, el Tribunal interamericano dejó abierto el procedimiento de supervisión de cumplimiento.

\section{Caso Kimel Vs. Argentina. Supervisión de Cumplimiento}

de Sentencia. Resolución de la Corte Interamericana de Derechos Humanos de 15 de noviembre de 2010

El asunto fue introducido por la Comisión el 19 de abril de 2007, originado en una denuncia del CELS y del CEJIL (del 6/12/2000). Eduardo Gabriel Kimel era un conocido periodista de investigación que escribió "La masacre de San Patricio" de la Orden Palotina (referido a un hecho ocurrido en la dictadura el 4/7/1976), dicho autor abordó el asesinato de cinco religiosos. Su libro criticó la actuación de las autoridades encargadas de la investigación de los homicidios, entre ellas la del juez Guillermo Rivarola; el magistrado mencionado por Kimel promovió finalmente una querella criminal por el delito de calumnias, quien fue condenado a un año de prisión en suspenso y una indemnización de \$20.000.

En el proceso ante la Corte IDH, el Estado admitió su responsabilidad, se allanó y reconoció como violados los artículos 8.1 y 13 de la $\mathrm{CADH}^{73}$.

En su fallo del 2 de mayo de 2008, ese Tribunal regional declaró por unanimidad que: "1. Acepta el reconocimiento de responsabilidad internacional efectuado por el Estado, en los términos de los párrafos 18 a 28 de esta Sentencia, y manifiesta que existió violación del derecho a la libertad de expresión, consagrado en el artículo 13.1 y 13.2 de la Convención Americana sobre Derechos Humanos, en relación con las obligaciones generales establecidas en los artículos 1.1 y 2 de dicho tratado, en perjuicio del señor Eduardo Kimel, en los términos de los párrafos 51 a 95 de la Sentencia. 2. Acepta el reconocimiento de responsabilidad internacional efectuado por el Estado, en los términos de los párrafos 18 a 28 de esta Sentencia, y manifiesta que existió violación al derecho a ser oído dentro de un plazo razonable, consagrado en el artículo 8.1

${ }^{73}$ Corte IDH, Caso Kimel Vs. Argentina, Supervisión de Cumplimiento de Sentencia, Resolución de la Corte Interamericana de Derechos Humanos 15 de noviembre de 2010, puntos resolutivos, párr. 3. 
de la Convención Americana sobre Derechos Humanos, en relación con la obligación general establecida en el artículo 1.1 de dicho tratado, en perjuicio del señor Eduardo Kimel, en los términos de los párrafos 96 y 97 de la presente Sentencia..."74.

Luego de varios años, el 28 de mayo de 2010 la Corte llevó a cabo la primera supervisión, y el 15 de noviembre la segunda. Dispuso que: "1. El Estado ha dado cumplimiento total a la obligación de realizar un acto público de reconocimiento de su responsabilidad (punto resolutivo décimo de la Sentencia), de conformidad con lo señalado en el Considerando de la presente Resolución. 2. Mantendrá abierto el procedimiento de supervisión hasta el cumplimiento de la obligación pendiente de acatamiento en el presente caso, a saber, el dejar sin efecto la condena penal impuesta al señor Kimel y todas las consecuencias que de ella se deriven (punto resolutivo séptimo de la Sentencia), de conformidad con lo señalado en los Considerandos de la presente Resolución"75.

En el país se dictó -finalmente- la Ley No 26.551 que modificó el artículo 110 del Código Penal ${ }^{76}$.

\footnotetext{
${ }^{74}$ Señaló la Corte que: “...3. El Estado violó el principio de legalidad consagrado en el artículo 9 de la Convención Americana sobre Derechos Humanos, en relación con los artículos 1.1 y 2 de la misma, en perjuicio del señor Eduardo Kimel, en los términos de los párrafos 61 a 67 del presente fallo”.

75 Resuelve: “...1. Requerir al Estado que adopte a la brevedad todas las medidas que sean necesarias para dar efectivo y pronto acatamiento al punto pendiente de cumplimiento que fue ordenado por el Tribunal en la Sentencia de fondo, reparaciones y costas de 2 de mayo de 2008, de conformidad con lo estipulado en el artículo 68.1 de la Convención Americana sobre Derechos Humanos. 2. Solicitar al Estado que presente a la Corte Interamericana de Derechos Humanos [...] un informe detallado y exhaustivo en el cual indique todas las acciones adoptadas para cumplir la medida de reparación que se encuentra pendiente de acatamiento, de conformidad con lo señalado en el punto declarativo segundo de esta Resolución, así como la información requerida en el Considerando de la misma. 3. Solicitar a los representantes de la víctima y a la Comisión Interamericana de Derechos Humanos que presenten sus observaciones al informe del Estado mencionado en el punto resolutivo anterior, en los plazos de cuatro y seis semanas, respectivamente, contados a partir de la recepción de dicho informe. 4. Continuar supervisando el punto pendiente de cumplimiento de la Sentencia de fondo, reparaciones y costas de 2 de mayo de 2008. 5. Requerir a la Secretaría de la Corte que notifique la presente Resolución al Estado, a la Comisión Interamericana de Derechos Humanos y a los representantes de la víctima" (Corte IDH, Caso Kimel Vs. Argentina, Supervisión de Cumplimiento de Sentencia, Resolución de la Corte Interamericana de Derechos Humanos 15 de noviembre de 2010, puntos resolutivos, párr. 3).

${ }^{76}$ La Cámara de Casación Penal el 10 de noviembre de 2011 (Causa No 13.272, Sala III, CNCP "Kimel, Eduardo Gabriel s/ Recurso de revisión") ha dejado sin efecto la condena, por lo que la Corte seguramente cerrará el caso.
} 


\section{Caso Cantos Vs. Argentina. Supervisión de Cumplimiento} de Sentencia. Resolución de la Corte Interamericana de Derechos Humanos de 26 de agosto de 2010

Con respecto al incumplimiento de los Tratados en el ámbito doméstico, este país fue por primera vez condenado por la Corte IDH en el año 2002 en el caso Cantos, por violentar los artículos 1.1, 8 y 25 de la $C A D H$, perjudicando el acceso a la justicia del reclamante. Ese Tribunal mandó a la Argentina -entre otros tópicos- a fijar nuevamente de manera razonable los gastos de un pleito por considerar que los determinados con anterioridad implicaban limitaciones económicas para el acceso a la justicia ${ }^{77}$.

En 2003, en el ámbito local no se dio total acatamiento al decisorio referido, invocándose razones de "derecho interno". Dijo - por ejemplo- la CSJN que la reducción de los emolumentos de los peritos oficiales que no habían participado en el juicio internacional afectaba el derecho de defensa. Sin embargo, la minoría entendió que el fallo debía respetarse en su totalidad por ser el mismo vinculante ${ }^{78}$.

A fin de dar respuesta con la totalidad de la sentencia interamericana, el Poder Ejecutivo Nacional dispuso por el Decreto 1313, del 11 de agosto de 2008, que por conducto de la Secretaría de Derechos Humanos del Ministerio de Justicia, se llevaran a cabo las actuaciones pertinentes.

La Corte IDH inició sucesivos trámites de supervisión: el 28 de noviembre de 2005, el 12 de julio de 2007, el 6 de julio de 2009 y el 26 de agosto de 2010.

De lo que antecede se infiere que este fallo todavía no fue cumplido in totum por la Argentina, y que continúa el trámite de supervisión.

\footnotetext{
77 En el derecho interno el señor Cantos que era propietario de un importante grupo empresario en la provincia de Santiago del Estero. En el año 1972 la entonces Dirección de Rentas local hizo varios allanamientos del que resultaron reclamaciones administrativas por una elevada suma de dinero. Luego de una transacción aparentemente incumplida por el Estado, el Señor Cantos demandó a la Provincia por la suma de 2.780 millones de pesos. Diez años después tal pretensión fue repelida por la Corte Suprema de la Nación quien rechazó la acción fijando en 140 millones de pesos las costas del pleito y condenando al nombrado a abonar dicho monto. El 28 de noviembre de 2002 la Corte IDH sostuvo, teniendo en cuenta el elevado cuantum de las costas del pleito, que el Estado violó los artículos 8 y 25 de la CADH y que, por ende, debía fijarse una nueva cifra.

${ }^{78}$ Corte Suprema de la Nación Argentina, Expte. 1307/2003, Decisorio del 21 de agosto de 2003, (véase el voto de la minoría Dres. Boggiano y Maqueda).
} 


\section{Caso Bulacio Vs. Argentina. Supervisión de Cumplimiento de Sentencia. Resolución de la Corte Interamericana de Derechos Humanos de 26 de noviembre de 2008}

En el asunto del epígrafe, el Tribunal regional interamericano condenó, el 18 de septiembre de 2003 a la Argentina por violar los artículos 4, 7, 8, 25 y 1.1 de la Convención ${ }^{79}$, a raíz de la muerte de un joven por parte de la policía. Dispuso allí que se investigue y se sancione a los responsables, y que sean indemnizados los familiares.

La Corte Nacional -en un interesantísimo decisorio, con algunas disidencias pero en concordancia argumental-acató a cabalidad aquella sentencia del Tribunal del Pacto de San José ${ }^{80}$, disponiendo que continúe el enjuiciamiento contra el imputado (Comisario Espósito) ${ }^{81}$.

Empero -vale la pena señalarlo-, en el ámbito doméstico no se concluyó todavía la nueva investigación ni se modificaron en su totalidad las normas domésticas implicadas, como lo había ordenado la Corte IDH.

Observamos en Espósito (Bulacio) un avance en la jurisprudencia inter$\mathrm{na}^{82}$. En efecto, sostuvo sin eufemismos el más Alto Tribunal del país -por mayoría- que “... la decisión de la Corte IDH (...) resulta de cumplimiento

\footnotetext{
${ }^{79}$ Corte IDH, Caso Bulacio Vs. Argentina, Sentencia de 18 de Septiembre de 2003, Serie C No 100. Puso énfasis allí la Corte Interamericana, siguiendo sus precedentes, que son inadmisibles las disposiciones sobre prescripción o de cualquier otro obstáculo de derecho interno (párr. 116) mediante los cuales se pretenda impedir la investigación (arts. 1.1, 2 y 25 del Pacto de Costa Rica). Ninguna disposición de la legislación doméstica puede impedir el cumplimiento de las obligaciones del Estado en cuanto a investigar y sancionar a los responsables (párr. 117) ni obstaculizar decisiones de órganos internacionales (párr. 119) se ha configurado, añadió, un caso de impunidad, por lo que el Estado debe concluir la investigación e informar sobre sus avances (párr. 191).

${ }^{80}$ Corte Suprema de la Nación Argentina, Espósito, Miguel Ángel s/ incidente de prescripción, E.224 39 del 23 de diciembre del 2004.

${ }^{81}$ Pese a las disidencias antes señaladas todos los integrantes de la Corte Nacional (con algunas variantes argumentales) han acatado el pronunciamiento aludido partiendo de la base de que ella como parte del Estado debe cumplir los fallos de la Corte Interamericana, aunque -en este caso- tal actitud perjudique el derecho de defensa en el derecho interno, que tiene raigambre constitucional. En este aspecto el Dr. Fayt puso de relieve que si bien es cierto que hay que acatar el fallo del aludido cuerpo regional (Fallos 321:3555), ello no significa que haya que restringir los derechos procesales de los individuos, la competencia de la Corte Interamericana -añadió- se refiere exclusivamente a la responsabilidad del Estado y no a la de los individuos.

${ }^{82}$ Véanse los Casos Laríz Irondo y Arancibia Clavel sus similitudes y diferencias con respecto a delitos de lesa humanidad, en GelLI, María Angélica, El Terrorismo y el desarrollo progresivo de un delito internacional, La Ley, 20 de septiembre de 2005.
} 
obligatorio para el Estado Argentino (art. 68.1, CADH), por lo cual también esta Corte, en principio, debe subordinar el contenido de sus decisiones a las de dicho Tribunal internacional ..." (párr. 6) ${ }^{83}$ [énfasis agregado] ${ }^{84}$.

\section{Caso Garrido y Baigorria Vs. Argentina. Supervisión de Cumplimiento de Sentencia. Resolución de la Corte Interamericana de Derechos Humanos de 27 de noviembre de 2007}

Los hechos motivo de estas actuaciones ocurrieron en la ciudad de Mendoza (Argentina) el 28 de abril de 1990. En esa fecha se produjo la desaparición forzada de los señores Raúl Garrido y Adolfo Baigorria, previa detención por parte de la policía local.

El Estado Nacional reconoció su responsabilidad ante la Corte IDH, por un hecho originado en una provincia.

Ese Tribunal condenó a la provincia a pagar una indemnización; a proceder a la identificación de los hijos extramatrimoniales del señor Raúl Baigorria; a investigar y sancionar a los autores; y a reintegrar los gastos.

Dispuso a la par tomar nota del reconocimiento efectuado por la Argentina acerca de los acontecimientos articulados en la demanda, como asimismo del reconocimiento de responsabilidad internacional, y concedió a las partes de un plazo de seis meses para arribar a un acuerdo sobre reparaciones.

El 27 de noviembre de $2007^{85}$ la Corte IDH efectuó una supervisión de cumplimiento de sentencia; tuvo en cuenta que durante la audiencia celebrada el 23 de noviembre del mismo año el Estado expresó su voluntad de acatamiento

83 Ídem, CSN, Fallos: 321:3555.

${ }^{84}$ La Corte IDH consideró que -como antes expresamos- Argentina había violado las normas domésticas e internacionales sobre la base del incumplimiento del derecho a la verdad y dispuso que Espósito continúe encausado. El juicio oral se desarrollará próximamente, el pleito lleva más de 20 años de tramitación. Hubo una solución amistosa en el año 2003, y el 17 de noviembre de 2004 la Corte IDH inició el procedimiento de Supervisión. Dejó sentado allí que el Estado Argentino había cumplido con gran parte de la sentencia interamericana, pero le requirió que adopte las medidas que sean necesarias para dar efecto y pronto acatamiento a los puntos pendientes de cumplimiento, esto es, terminar la investigación, sancionar a los responsables y dictar las medidas legislativas que le habían sido requeridas. El 26 de noviembre de 2008 se llevó a cabo otra supervisión de cumplimiento donde se le requirió a la Argentina que prosiga y concluya la investigación y que garantice que no se repitan los hechos como los del presente caso, adoptando las medidas de cualquier índole que sean pertinentes. Dejó en claro que continuaría supervisando el cumplimiento de sentencias.

${ }^{85}$ Corte IDH, Caso Garrido y Baigorria Vs. Argentina, Supervisión de Cumplimiento de Sentencia. Resolución de la Corte Interamericana de Derechos Humanos, de 27 de noviembre de 2007. 
y, en consecuencia, consideró la alta utilidad de la audiencia celebrada para supervisar los puntos pendientes, en la cual ha quedado plasmada la buena voluntad y espíritu de cooperación de las partes: "en particular, valora [dijo] que los representantes del Estado, la Comisión y de uno de los familiares hayan expresado mediante un acta el propósito y compromiso común de que aquellos puntos sean acatados. Por ello, alienta a las autoridades estatales a concretar la reunión programada (supra Visto 15), queda a la espera de que las partes informen los resultados de la misma y, de ser posible, de un cronograma y programa de acción vinculados al cumplimiento de los puntos pendientes de la Sentencia de Reparaciones dictada en el presente caso" ${ }^{86}$.

\section{Corte IDH. Caso Bueno Alves Vs. Argentina. Supervisión de Cumplimiento de Sentencia. Resolución de la Corte Interamericana de Derechos Humanos de 5 de julio de 2011}

Responde a hechos acontecidos en el año 1988. Se reconoció responsabilidad en el caso pero se litigó en materia de reparaciones pecuniarias. La Corte IDH dictó sentencia el 11 de mayo de 2007. El reclamante -de nacionalidad uruguaya - fue detenido y torturado por la Policía Federal. Con el allanamiento del Estado Argentino las cosas se facilitaron, ya que sólo resta fijar la indemnización compensatoria e investigar los hechos denunciados ${ }^{87}$.

Cabe poner de relieve que otro de los querellantes y damnificados por el mismo asunto fue Carlos A. Pérez Galindo, el abogado de Bueno Alves que también resultó preso en dicho operativo.

En base a lo ordenado por el Tribunal regional (investigar), la Corte Suprema Argentina el 29 de noviembre de 2011 dictó sentencia disponiendo -por mayoría- dejar sin efecto la prescripción que favorecía al imputado (CSN, causa René Jesús Derecho, sentencia del 29-11-2011).

\footnotetext{
${ }^{86}$ Corte IDH, Caso Garrido y Baigorria Vs. Argentina, Supervisión, cit., párr. 12. Finalmente, declaró que mantendrá abierto el procedimiento de supervisión con respecto a la localización de los hijos extramatrimoniales de Raúl Baigorria y en lo atinente a la investigación de los hechos que condujeron a la desaparición de Garrido y de Baigorria, y la eventual sanción a los responsables. Dejó también aclarado que seguirá supervisando los puntos pendientes de cumplimiento.

${ }^{87}$ Véase BAZÁn, Víctor, La Corte Suprema de Justicia de la Nación y algunas líneas jurisprudenciales salientes en materia de derechos fundamentales, La Ley, Suplemento Constitucional, 29 de marzo de 2012, p. 23.
} 
Todo ello en cumplimiento de lo dispuesto por la Corte IDH habida cuenta que según el máximo cuerpo judicial del país, los fallos del Tribunal del Pacto de San José son obligatorios para el ámbito doméstico.

\section{Casos Argentinos que todavía no se encuentran en supervisión de cumplimiento}

Los asuntos Jorge Fontevecchia, Milagros Fornerón, Jorge Fernando Gran$\mathrm{de}^{88}$, Iván Eladio Torres, Juan Francisco Bueno Alves ${ }^{89}$, están en trámite ante el Tribunal regional, sin que todavía hayan pasado a la etapa de ejecución de cumplimiento, como a continuación sintéticamente lo explicamos.

1. Jorge Fontevecchia y Hector D'amico Vs. República Argentina (caso 12.524). Responde a hechos acontecidos en el año 1995. Argentina hizo su contestación

\footnotetext{
${ }^{88}$ Vale la pena poner de relieve que recientemente la Corte IDH repelió la demanda interpuesta contra este país. En el caso Grande Vs. Argentina (sentencia del 31 de agosto de 2011) ese Tribunal rechazó la pretensión de indemnización del presunto afectado por un supuesto proceso penal irregular. El caso fue iniciado por Fernando Grande ante la CIDH, quien finalmente el 4 de mayo de 2010 lo giró a la Corte Interamericana. Se impetraba una indemnización de 800.000 dólares, por error judicial. En efecto "La Comisión y el representante alegaron la violación de los artículos 8 y 25 de la Convención Americana en el referido procedimiento contencioso administrativo. Al respecto, la Comisión, para sustentar dicha violación, indicó en términos generales que: a) en el trámite del reclamo indemnizatorio no se tomó en cuenta la ilegalidad de la prueba recabada en el fuero penal ni el lapso prologando para tomar la decisión en la instancia penal, y b) el Estado no hizo nada para remediar la alegada violación del debido proceso en la jurisdicción penal, pese a que reconoció la irregularidad en la vía contencioso administrativa. Por su parte, el representante coincidió con los argumentos expresados por la Comisión, y en especial, señaló que la Sala Segunda de Apelaciones en lo Contencioso Administrativo no consideró el accionar ilegítimo del Estado respecto a la ilegalidad de la prueba y la duración del proceso penal [...] Al respecto, el Tribunal observa que ni la Comisión ni el representante presentaron alegatos y hechos específicos y autónomos ocurridos durante la tramitación del reclamo indemnizatorio en la jurisdicción contenciosa administrativa que puedan derivar violaciones al debido proceso y garantías judiciales. En consecuencia, no se demostró la responsabilidad internacional del Estado por la violación de los artículos 8 y 25 de la Convención Americana, en perjuicio del señor Jorge Fernando Grande" (Corte IDH, Caso Grande Vs. Argentina, Sentencia de 31 de agosto de 2011, Serie C No 231, párrs. 92 y 93).

${ }^{89}$ En el citado asunto la CSN de Argentina, el 29-11-2011 se pronunció por mayoría -aquí el querellante (en el Derecho interno) fue Carlos A.B. Pérez Galindo-, que no existió prescripción de la acción penal pese al transcurso del tiempo. El argumento fue que así lo dispuso la Corte IDH en "Bueno Alvez"; cuyo fallo -dijo la la CSN- es obligatorio en el ámbito domestico. Vale pena resaltar que se citó la Doctrina Legal sentada en "Bulacio-Espósito". La minoría -en cambio- desconoció la vinculatoriedad de los pronunciamientos del Tribunal regional, ha sostenido que tal decisión no puede dejar sin efecto el fallo nacional que había declarado la prescripción de la acción penal. La minoría dejó sentado que distinta es la solución en los delitos de lesa humanidad (in re D. 1682XL. Recurso de hecho. Derecho, René Jesús s/ incidente de prescripción de la acción penal. Causa № 24.79).
} 
de demanda aludiendo a los avances en materia de libertad de expresión operados desde 2003 a la actualidad, sin hacer reconocimiento de responsabilidad y puso el asunto a consideración de la Corte IDH. La presentación se llevó a cabo el 10 de junio de 2011. El 29 de noviembre de dicho año ese Tribunal dictó la sentencia de fondo, reparaciones y costas, condenando a la Argentina por violación del art. 13 de la $\mathrm{CADH}$ en relación con el art. 1.1 de la misma ${ }^{90}$.

2. Milagros Fornerón y Leonardo Aníbal Fornerón Vs. República Argentina (caso 12.584). Responde a hechos acontecidos en el año 2000. Se está trabajando con la Provincia de Entre Ríos en la elaboración de un acuerdo entre las partes con el reconocimiento de responsabilidad de la provincia por los hechos violatorios de derechos de la niña Milagros y su padre biológico. La Secretaría de Derechos Humanos y Cancillería preparan en paralelo la contestación de demanda que versará enfáticamente sobre la irracionalidad de los montos pecuniarios pretendidos en concepto de reparaciones por los peticionarios.

3. Jorge Fernando Grande Vs. República Argentina (caso 11.498). Responde a hechos acontecidos en el año 1980. El caso se litiga en la Corte IDH, alegando aplicación de excepciones preliminares, cuestiones de fondo y reparaciones. Hubo audiencia pública en el mes de mayo de 2011. El 17 de junio de 2011 vence plazo para presentar alegatos finales.

4. Iván Eladio Torres Millacura Vs. Argentina (caso 12.533). Caso que responde a hechos acontecidos en la Provincia de Chubut en el año 2003 -desaparición forzada de persona-. El Estado Nacional reconoció responsabilidad en el caso en subsidio de la provincia de Chubut en el marco de la audiencia pública llevada a cabo ante la Corte IDH en el mes de mayo de 2011. Finalmente, la Corte dictó sentencia el 13 de septiembre de 2011, ordenando continuar la búsqueda del señor Iván Eladio Torres Millacura, así como la implementación por parte del país, en un plazo razonable, de un programa o curso obligatorio sobre derechos humanos dirigido a los policías de todos los niveles jerárquicos de la provincia de Chubut; deberá pagar las cantidades fijadas [...] por concepto de indemnización por daño material e inmaterial, y por reintegro de costas y gastos, según corresponda; deberá reintegrar al Fondo de Asistencia Legal a Víctimas de la Corte Interamericana de Derechos Humanos la suma erogada durante la tramitación del presente caso; además,

\footnotetext{
${ }^{90}$ El citado pronunciamiento declara -como se dijo- que Argentina debe dejar sin efecto la condena civil impuesta al señor Jorge Fonteveccia y al señor Hector D’amico, así como todas sus consecuencias.
} 
dentro del plazo de un año a partir de la notificación de esta sentencia, el Estado deberá rendir al Tribunal un informe sobre las medidas adoptadas para darle cumplimiento; y conforme a lo establecido en la Convención Americana sobre Derechos Humanos, la Corte supervisará el cumplimiento íntegro de la Sentencia y dará por concluido el caso una vez que el Estado haya dado cabal ejecución a lo dispuesto en la misma (párr. 213).

\section{Casos en la Provincia de Buenos Aires}

En la Provincia de Buenos Aires podemos citar algunos asuntos que no han ido a la Corte IDH pues -en su momento- las partes arribaron a una Solución Amistosa en el ámbito de la Comisión IDH. Vale la pena tener presente que continúan en trámites en el ámbito bonaerense, hasta cumplir con todas las Recomendaciones, los siguientes asuntos:

\section{Caso Sergio Andrés Schiavini y María Teresa Schnack (Caso No 12.080)}

El hecho que ha motivado las actuaciones de marras ocurrió en la ciudad de Lomas de Zamora (Provincia de Buenos Aires), el 29 de mayo de 1991. A raíz de un robo acudió un patrullero policial que al repeler la acción de los asaltantes terminó ocasionándole la muerte al Sr. Schiavini quien había sido tomado como rehén ${ }^{91}$. Ante esas circunstancias, el gobierno argentino manifestó su voluntad de que se tenga por acreditado que hubo un uso excesivo de la fuerza por parte de los agentes de la policía provincial. Como consecuencia de ello, llevó a cabo el Acuerdo de Solución Amistosa firmado del 2 de marzo de 2005 y aprobado el 27 de octubre de 2005, que a su vez fue ratificado por el Estado Nacional ${ }^{92}$. Adviértase que se trató de un hecho

\footnotetext{
${ }^{91}$ El 3 de febrero de 1998 se promovió la denuncia ante la Comisión que fue declarada admisible el 27 de febrero de 2002.

${ }_{92}$ Decreto No 574/2005 del 2 de junio de 2005. Aquí la autoridad nacional se consideró obligada en virtud de la Cláusula Federal del Pacto de San José de Costa Rica (art. 28). Se convino allí constituir un Tribunal Arbitral "ad hoc" a efectos de determinar el monto de las reparaciones pecuniarias. Se pactó también conformar un grupo de trabajo técnico al que se invitará a participar al gobierno provincial a efectos de realizar estudios y dirigencias necesarias para someter a consideración del Poder Legislativo y, en su caso, a las autoridades que fueran competentes para adaptar a los estándares internacionales la normativa actualmente en vigencia.
} 
acaecido en una provincia. Allí el Estado Nacional se hizo cargo de la situación, e "invitó" a la provincia a colaborar en la Solución Amistosa (doctrina del art. $28 \mathrm{CADH})$.

\section{Caso Fernando Horacio Giovanelli (Caso No 12.298)}

La víctima -de 29 años de edad- fue detenida por la policía de la Provincia de Buenos Aires el 17 de octubre de 1991, y en la Comisaría Tercera de Quilmes fue golpeada brutalmente y arrojada a la vía pública donde ha sido asesinado por un funcionario de esa dependencia. Se llegó a una Solución Amistosa a través del gobierno $\mathrm{Nacional}^{93}$, ratificada por el Decreto No $1.023 / 2008$.

Importa poner de relieve que, mediante el Acta del 14 de octubre de 2003 y el Decreto Provincial No 1.859 del 15 de octubre del mismo año, el gobierno bonaerense había reconocido deficiencias en la investigación judicial. Esta actitud demuestra que en tal situación también ha habido una "colaboración" para cumplir los Tratados entre el Gobierno local y el Estado Federal ${ }^{94}$.

En la solución amistosa, lo mismo que en el asunto Schiavini, la República Argentina se comprometió a elaborar un proyecto que establezca un procedimiento para la tramitación de las peticiones que se sustancien ante la Comisión y ante la Corte Interamericana de Derechos Humanos, que contemple el proceso de toma de decisiones incluyendo la institución de la "solución amistosa", y un mecanismo de tratamiento de las recomendaciones de la Comisión Interamericana de Derechos Humanos, y un procedimiento de cumplimiento de las sentencias de la Corte Interamericana de Derechos Humanos, en consonancia con lo prescripto en el artículo 28 (cláusula federal) en relación con los artículos 1, incisos 1 (obligación genérica de respeto y garantía) y 2 (deber de adoptar disposiciones de derecho interno), de la Convención Americana de Derechos Humanoss5.

\footnotetext{
${ }_{93}$ Informe No 81/08 donde el Estado argentino, el gobierno de la Provincia de Buenos Aires y los peticionarios convinieron abrir un espacio de diálogo para arribar a una Solución Amistosa bajo los auspicios de la Comisión.

${ }^{94}$ En la solución amistosa se dispuso la creación de un Tribunal "ad hoc" para fijar la indemnización.

95 Informe No 81/08, Caso No 12.298, Solución Amistosa, Fernando Giovanelli, Argentina, 30 de octubre de 2008, párr. 19.
} 


\section{Caso Gabriel Egisto Santillán (Caso No 12.159)}

Todo giró sobre un hecho ocurrido el 8 de diciembre de 1991, cuando un menor de 18 años fue muerto por la policía local que perseguía por la supuesta sustracción de un vehículo en la ciudad de Merlo (Provincia de Buenos Aires). Aquí el Poder Ejecutivo bonaerense rechazó su responsabilidad ${ }^{96}$, mas el gobierno nacional la reconoció, admitiendo la violación que se le imputó. Finalmente, se arribó a una solución amistosa que fue aprobada por el gobierno nacional el 28 de mayo de 2008. Allí se dispuso la reparación económica y medidas de reparación no pecuniarias.

\section{Caso Jorge Omar Gutiérrez y familia (Caso 12.221)}

En el presente asunto un subcomisario de la Policía local que prestaba servicios en la Comisaría de Avellaneda -que investigaba un caso de corrupciónfue asesinado con un disparo en la nuca, el 29 de agosto de 1999, mientras viajaba en un tren ${ }^{97}$. Adviértase que en estas actuaciones el Estado informó de la emisión del Decreto No 3.241/2006, donde “...el Poder Ejecutivo de la provincial reconoció la responsabilidad del Estado y se comprometió a adoptar las medidas que fueran necesarias...". Finalmente, la CIDH admitió lo allí expresado y llevó a cabo una serie de Recomendaciones ${ }^{98}$, a saber: “...Realizar una investigación completa, imparcial, efectiva y pronta de los hechos, con el objeto de establecer y sancionar la responsabilidad intelectual y material de todas las personas que participaron en los hechos relacionados con la ejecución de Jorge Omar Gutiérrez [...] Realizar una investigación completa, imparcial, efectiva y pronta con respecto de las personas adscritas a los diferentes órganos estatales que han estado involucradas en las investigaciones y proceso llevados a cabo con ocasión de los hechos del presente caso, a fin de determinar la responsabilidad (administrativa, disciplinaria, penal o de otra índole que aplique) por las deficiencias en la investigación,

\footnotetext{
${ }^{96}$ No obstante, a través de una nota del 1 de junio de 2007, manifestó su voluntad de "colaborar en el seguimiento de los expedientes individualizados".

${ }^{97}$ El expediente quedó radicado en la Comisión IDH donde finalmente se llegó a una Solución Amistosa.

${ }^{98}$ Comisión Interamericana sobre Derechos Humanos, Informe No 63/11, Caso 12.221, Fondo, Jorge Omar Gutiérrez y Familia, Argentina, 31 de marzo de 2011, párr. 146.
} 
procesamiento de los hechos y obstaculización, que ha derivado en la impunidad [...] Reparar adecuadamente a los familiares de Jorge Omar Gutiérrez por las violaciones de sus derechos humanos"99.

Se advierte en estas actuaciones otro avance importante ya que la Provincia reconoció expresamente su responsabilidad y se comprometió a realizar las medidas necesarias para profundizar la investigación (Decreto No 3.241 del 4/12/2006).

\section{RESUMEN FinAL}

\section{A. Recepción de las sentencias de la Corte IDH en el ámbito interno}

\section{Obligatoriedad de las sentencias}

En lo que hace a la naturaleza de las sentencias de la Corte, digamos que son obligatorias (art. 68.1 CADH) y que los Estados están compelidos a cumplirlas en todo caso en que sean parte. En la hipótesis de que el fallo disponga una indemnización compensatoria, el mismo puede hacerse efectivo por las vías adjetivas domésticas atinentes a la ejecución de las sentencias contra el Estado (art. 62.1 y 68.2 CADH).

El artículo 65 de la CADH dispone que la Corte IDH debe someter a consideración de la Asamblea General de la OEA asuntos en que los Estados desoigan sus fallos. Pese a ello -como vimos- los países no han acatado a pie juntillas todos los pronunciamientos de ese Tribunal. Empero lo cierto es que progresivamente se ha adelantado mucho en este sentido y los decisorios de ese cuerpo regional cada vez tienen más peso.

El mal ejemplo es Venezuela que se ha negado a aceptar la jurisdicción de la Corte regional. En el año 2011 ese país ha sido condenado en el asunto "Caso Chocrón Chocrón Vs. Venezuela"100, mas la Sala Constitucional del Tribunal Supremo de Justicia, lamentablemente lo ha declarado inejecutable ${ }^{101}$.

La OEA deberá tomar medidas para que estas cosas no sucedan, ya que perjudican el modelo interamericano.

\footnotetext{
99 Para activar y cumplir dichas Recomendaciones en el derecho interno provincial, en junio de 2011, tomó intervención el Poder Judicial y en especial el agente Fiscal a cargo del expediente, quien viene impulsando la conclusión del mismo a través de la investigación de los hechos denunciados.

${ }^{100}$ Corte IDH, Caso Chocrón Chocrón Vs. Venezuela, Sentencia de 1 de julio de 2011, Serie C No 227.

${ }^{101}$ Con fecha 17 de octubre de 2011.
} 


\section{Mecanismos de recepción}

La problemática que surge de este subtítulo aparece con ribetes más complicados en los Estados Federales -en la Argentina hablamos de las autonomías provinciales-, habida cuenta de que la responsabilidad que emana de los artículos 1.1, 2 y 28 del Pacto de San José de Costa Rica surge por vía de principio contra el Estado central, sin perjuicio de las medidas o conductas que lleven a cabo las provincias.

Hemos visto que de la interpretación que se infiere del nombrado artículo 28, si bien el mismo atribuye una responsabilidad primaria para el Estado Nacional, las provincias no pueden desligarse, ni la Nación valerse del referido precepto para disminuir la suya, ya que todo el país sin distinción de competencias se encuentra obligado a asegurar la plena vigencia de los derechos humanos que surgen de las Convenciones aprobadas y del ius cogens.

La República Argentina no ha instrumentado, hasta el presente, un carril de recepción de las sentencias de la Corte IDH ni reglas expresas para que las provincias se incorporen de manera efectiva a este modelo de diálogo entre la jurisdicción Nacional y la local, aunque se está trabajando en este sentido.

Como anticipamos, en el país, actúan de consuno y con mucha eficiencia dos organismos, estos son, el Ministerio de Justicia y Derechos Humanos y la Cancillería. En la práctica, cuando advierten la existencia de una infracción que les compete, se propicia generalmente un espacio de "acuerdo" con los reclamantes. La modalidad de recepción es lisa y llana pues los fallos de la Corte no se consideran extranjeras, y por ende, no necesitan ningún tipo de homologación ni exequátur. La Embajada Argentina en Costa Rica envía los fallos a dichos órganos del Poder Ejecutivo Nacional, quienes lo canalizaban o en cualquiera de los tres Poderes que debe cumplir el fallo interamericano.

En este orden de pensamiento, si el Poder Ejecutivo detecta una eventual violación, propone, generalmente, un reconocimiento de responsabilidad internacional y el diálogo con los peticionarios. Dentro de tal marco de referencia, se propicia, en las hipótesis que corresponda, una Solución Amistosa ante la Comisión IDH o ante la Corte IDH.

\section{Ejecución y cumplimiento}

En la Argentina -tal cual lo adelantamos- no existen normas constitucionales que regulen la forma de recepción de las sentencias de la Corte IDH, por 
lo que podríamos hablar de que estamos ante el esquema de recepción "lisa y llana”. Además, la jurisprudencia, sobre todo la Suprema Corte de Justicia de la Nación, ha sostenido que las decisiones de ese órgano supranacional son obligatorias para el caso concreto en el campo doméstico. El artículo 75 inc. 22 de la Constitución Nacional (reformada en 1994) le da a la CADH y a otros documentos internacionales que enumera jerarquía constitucional.

\section{Supervisión del cumplimiento de las sentencias efectuado por la Corte IDH}

Puntualizamos que dicho Tribunal regional no sólo condena a los Estados cuando infringen los Tratados internacionales o el ius cogens, o la jurisprudencia de la propia Corte IDH; sino que en los últimos años viene ejerciendo una importantísima labor convirtiéndose en una especie de "juez de ejecución de sus fallos", controlando a pie juntillas que los países acaten sus decisorios.

El art. 69 de su nuevo Reglamento señala que ese trámite se debe realizar mediante informes, observaciones de la CIDH, como Estatales, y consideraciones de las víctimas. Esto significa que tal normativa ha regulado expresamente el modo de ejecución de los pronunciamientos del Tribunal aludido, aunque desde antiguo -a partir del caso Baena Vs. Panamá-, lo había puesto en práctica sosteniendo que se trata de una etapa pos adjudicativa que no estaba prevista con anterioridad. El fundamento que se utilizó a esos fines, en el asunto de marras, fue que la jurisdicción comprende la facultad de administrar justicia y no solo se limita a declarar el derecho, sino que también le corresponde la supervisión del cumplimiento de lo juzgado.

\section{B. División de poderes y federalismo}

Del artículo 28 del Pacto de San José se infiere que, cuando se trate de un Estado Federal, el Gobierno Nacional debe cumplir todas las disposiciones pertinentes con respecto a cualquiera de sus tres Poderes.

Argentina le ha dado preferencia a la herramienta del reconocimiento de responsabilidad internacional, el diálogo con el peticionario y la instrumentación de políticas públicas como métodos de no repetición en casos futuros.

Dentro de este marco de referencia, la solución amistosa ha sido propiciada y en particular, en numerosas oportunidades, en la inteligencia de que este modelo constituye la herramienta más idónea para promover y fortalecer el sistema de protección internacional de los derechos humanos. 
En varios casos el Estado ha propuesto la constitución de una mesa de diálogo con las víctimas, con el objetivo de explorar la posibilidad de arribar a un acuerdo de solución amistosa.

Para el afectado la obtención de un pronunciamiento de responsabilidad estatal plasmado en un acuerdo de solución amistosa, demanda un tiempo sensiblemente menor que si el caso llegase a conocimiento de la Corte Interamericana de Derechos Humanos (Corte IDH).

La utilización de esta vía releva a la víctima de tener que nuevamente alegar y demostrar que han sido violentados sus derechos o los de sus deudos ante la Corte IDH. También es útil para el Estado pues a través de esta herramienta cumple con el objetivo de sujetar y, en su caso, adecuar su conducta a los principios y normas consagradas por el ordenamiento jurídico, además de ser una alternativa eficiente en el desarrollo de sus políticas públicas de derechos humanos.

De la interpretación armónica de los arts. 1.1, 2 y 28 de la CADH, surge sin hesitación que cualquiera de las provincias o la propia Ciudad Autónoma de Buenos Aires están sometidas al sistema del Pacto, y todo incumplimiento por parte de ellos implica responsabilidad del Estado Federal.

Desde este punto de mira es necesario -tal cual lo vimos-deslindar cuál es la situación de los Estados provinciales en la hipótesis de falta de acatamiento. No olvidemos que como expresa Bidart Campos, éstos no tienen responsabilidad jurídica internacional propiamente dicha y por ende no forman parte del Tratado, lo que no significa que queden exentos de las eventuales consecuencias por ausencia de acatamiento.

Como dice Dulitzky ${ }^{102}$, "aun cuando el gobierno central no adopte las medidas necesarias para que sus unidades componentes puedan dar efectividad al tratado, las entidades federales no por ello están eximidas de cumplir con la Convención. Tampoco las entidades federales quedan desligadas de toda obligación de cumplir con la Convención bajo el argumento que el gobierno central es el responsable internacional" [...] "En sentido concordante, el Comité de Derechos Humanos de Naciones Unidas ha indicado que el sistema de gobierno federal entraña la responsabilidad de las provincias en la observancia de muchos de los derechos previstos en el Tratado, que puede requerir la adopción de disposiciones normativas y medidas tomadas en el

${ }^{102}$ Dulitzky, Ariel, Federalismo y Derechos Humanos, ob. cit., p. 217. 
plano provincial para asegurar la observancia de los derechos enunciados. Por eso, el artículo 28 debe entenderse como extendiendo las obligaciones que resultan de la Convención Americana a cada unidad componente de la Federación" ${ }^{103}$.

En la Argentina, repetimos, que de los artículos 5 y 31 de la Carta Magna Nacional se infiere que cada provincia puede dictar su propia Constitución, bajo el sistema Representativo, Republicano y Federal (art. 5), sin perjuicio de advertir, en su artículo 128, que los Gobernadores de provincia son agentes naturales del Gobierno Federal para el cumplimiento de la Constitución y las Leyes de la Nación.

Enfocados en nuestra problemática, podría concebirse que el incumplimiento reiterado de una provincia de la sentencia de la Corte IDH y/o de los Tratados internacionales pertinentes podría generar la posibilidad, en situaciones de extrema gravedad, de la intervención Federal (art. 6 Constitución Nacional), en la medida que de ese modo se violen al extremo los principios, declaraciones y garantías de la Corte Magna Federal (art. 5, cit.).

En concordancia con el artículo 28 del Pacto, la Corte Suprema de la Nación viene sosteniendo que la falta de acatamiento de los convenios internacionales implica una "cuestión federal" y que los damnificados pueden solucionar sus agravios ante ese órgano, a través del recurso extraordinario Federal, que desde antiguo regula el artículo 14 de la Ley No 48.

\section{Experiencias Argentinas}

El asunto Verbitsky -ya analizado- es un caso paradigmático que podemos citar para demostrar el deslinde de competencias que ha hecho nuestra Corte Suprema Nacional, infiriéndose del mismo que la legislación provincial podría ser inconstitucional en la medida que sea incompatible con una norma internacional. Allí se ordenó a la Provincia de Buenos Aires que adecue su legislación y su práctica -en materia carcelaria- a los estándares internacionales. Se dijo a la par que el gobierno central es responsable primario de asegurar que se acaten las directivas que nacen de los Tratados internacionales; y que las provincias deben cumplirlos, como asimismo que la Nación no puede eximirse de las consecuencias internacionales aduciendo responsabilidad de las entidades provinciales.

\footnotetext{
${ }^{103}$ Comité de Derechos Humanos, Observaciones finales: Argentina 03/11/2000. CCPR/CO/70/ARG, citado por Dulitzky, Ariel, Federalismo y Derechos Humanos, ob. cit., p. 217.
} 
El país ha sido condenado por incumplimiento de las sentencias del Tribunal regional en los casos Bayarri, Kimel, Cantos, Bulacio, Garrido y Baigorria y otros, en los que la Corte IDH continúa interviniendo para que sus pronunciamientos sean acatados. Por ejemplo, en Bulacio dispuso, en su sentencia condenatoria, que se investigue y se sancione a los responsables del asesinato ya comentado.

La Corte Federal, en el ámbito de su competencia, ha impulsado el acatamiento de los fallos de la Corte IDH, y en ese sentido los órganos inferiores de la justicia revirtieron algunos decisorios, por ejemplo el que declaraba la prescripción de la acción penal, a fin de que "se llegue a la verdad" (derecho a la verdad), como lo había indicado el Tribunal supranacional ${ }^{104}$.

\section{La situación en la Provincia de Buenos Aires.}

Hemos citado algunos casos bonaerenses que se tramitan contra la Argentina en la Comisión IDH (no ya en la Corte IDH). Lo cierto es que esta Provincia en varios de ellos, en coordinación con las autoridades nacionales -y esto ha sido un importante avance-, reconoció expresamente su responsabilidad, inclusive -como vimos- ha dictado normas locales para impulsar investigaciones.

${ }_{104}$ Corte IDH, Caso Bulacio Vs. Argentina, cit. 
